\title{
Stratigraphic discriminatory potential of heavy mineral analysis for the Neogene sediments of Belgium
}

\author{
JASPER VERHAEGEN \\ VPO, Planning Bureau for the Environment and Spatial Development, Department of Environment, Flemish Government, Koning \\ Albert II-laan 20, 1000 Brussels, Belgium; jasperverhaegen@vlaanderen.be.
}

\begin{abstract}
The Neogene units of Belgium cannot always be easily distinguished based on visual inspection and correlation across the basin is not straightforward. To aid in the stratigraphic interpretation of units, the discriminatory potential of heavy minerals has been determined. In this study, heavy mineral composition is combined with grain size analysis, providing information on the bulk sediment. Based on heavy mineral composition important interpretations could be made, such as (1) a different provenance between the Dessel Member and the Hageland Diest sand, making it improbable that they were deposited at the same time, (2) the Kasterleesensu-Gulinck unit of the eastern Antwerp Campine should be redefined as a lower Mol Formation unit or as a lateral equivalent of the typical Kasterlee Formation to the west, affected strongly by southern continental sediment input, and (3) the Waubach Member in the Ruhr Valley Graben should be split into two separate units, with the upper unit correlated with the Mol Formation and the lower unit, possibly the Inden Formation, correlated with the Diest Formation and Kasterlee Formation. The ' $\mathrm{X}$ ' unit of the Maaseik core is likely a local transitional unit which cannot be directly correlated with a unit in the Campine Basin.
\end{abstract}

KEYWORDS: Heavy mineral composition, stratigraphy, grain size, Miocene, Pliocene, Campine Basin.

\section{Introduction}

The Neogene sediments at the southern edge of the North Sea Basin are mostly glauconite-rich sand deposits. The different formations can be recognized based on differing amounts of glauconite, different grain size characteristics and/or varying clay content and clay mineralogy. As these parameters also vary considerably within the formations and gradually across formation boundaries, an exact definition of the different units at a certain location is not always straightforward.

Heavy minerals may provide an additional argument for the stratigraphic definition of certain units. Heavy mineral composition is commonly used in the Dutch Pliocene and Quaternary stratigraphy for the correlation of units, certainly in units lacking biostratigraphical evidence (e.g. Westerhoff, 2009). It must be noted, though, that the heavy mineral composition should preferably be used in combination with other sediment characteristics in a stratigraphic study. Heavy mineral composition is primarily related to sediment provenance, which may be the same for different units or may vary at different locations for the same unit (Morton \& Hallsworth, 1994; 1999; Mange \& Wright, 2007). As such, these variations in sediment provenance recognized based on heavy mineral composition may correlate well with formation boundaries in certain cases yet they mainly serve to confirm or disprove correlations made based on other proxies.

A large amount of heavy mineral data of the Neogene units of Belgium were collected in the $20^{\text {th }}$ century. These data are largely summarized in Geets \& De Breuck (1991) for all Miocene and Pliocene formations, yet in this summary no coupling is made with depth, biostratigraphy or lithology. A statistical analysis of available literature data of the Belgian Neogene and available data of the Dutch Neogene from the Dutch Geological Survey was done in Verhaegen et al. (2019). Based on this analysis, there is an increase in tourmaline, staurolite and $\mathrm{Al}_{2} \mathrm{SiO}_{5}$ polymorph (kyanite, sillimanite and andalusite) content relative to epidote and amphibole content from the northwest to the southeast of the basin and from the lower Miocene to the Pliocene. This trend can be related to an increased input of southern continental sediments delivered by the Rhine-Meuse river system throughout the Neogene. This result is very similar to older models, going back to Edelman \& Doeglas (1933). The variation in garnet content relative to the ultrastable minerals zircon and rutile is rather interpreted as an indication of the degree of weathering which has affected the sediment prior to or after deposition (Verhaegen et al., 2019).

In this study, new heavy mineral data of the main Miocene units and the Pliocene Mol and Kieseloolite Formations are presented. In contrast to the summarizing study of Geets \& De Breuck (1991), these data are analyzed on the member-level and coupled with grain size distribution data. The new data are shortly discussed in terms of provenance variations, validating earlier results. The main goal of this study is to use these data, in combination with the results of the literature study in Verhaegen et al. (2019), in a stratigraphic framework. Recent advances in the Neogene stratigraphy of Belgium are taken into account as an assessment is made of the potential of heavy mineral data for stratigraphic purposes for the Neogene of the southern North Sea Basin.

\section{Geological setting}

The Neogene units of Belgium were largely deposited in the Campine Basin, which is a subsiding area north of the Brabant Massif and west of the Ruhr Valley Graben (RVG) (Vandenberghe et al., 2004). A thick layer of sediments was also deposited in the strongly subsiding RVG in the east (Vandenberghe et al., 2005). The Miocene units discussed in this paper are (1) the lowermiddle Miocene Berchem Formation in the Antwerp Campine area with the Edegem, Kiel and Antwerpen Members, (2) the lower-middle Miocene Bolderberg Formation in the Limburg Campine area with the Houthalen and Genk Members, (3) the Tortonian to Messinian Diest Formation in the Campine Basin and Hageland area with the Dessel Member at its base and the overlying Diest Sand, (4) the Messinian Kasterlee Formation in the eastern Antwerp area and Limburg Campine area, and (5) the Breda Formation and the lower part of the Kieseloolite Formation in the RVG (Fig. 1, areas indicated on Fig. 2). Some Pliocene data are presented as well of the Mol Formation in the eastern Campine area and the Kieseloolite Formation in RVG.

Most of these units consist of marine glauconite-rich sand yet there are also some continental quartz-dominated units such as the Kieseloolite Formation, the Mol Formation and the Genk Member of the Bolderberg Formation. Samples of the Kasterlee Formation and Mol Formation are classified using the current working definition, yet the Kasterlee Formation is separated into a lower clayey part (clayey Kasterlee unit) and an upper sandy part (Kasterlee-sensu-Gulinck) in the eastern Antwerp Campine area, east of the village of Kasterlee. Possibly, the upper sandy part of the Kasterlee Formation is a lower unit of the Mol Formation (Vandenberghe et al., 2020, this volume). The Kasterlee Formation from the type area west of Kasterlee is referred to as the typical Kasterlee Formation. Similarly, the Waubach Member of the Kieseloolite Formation is split into a lower and upper Waubach Member.

The first elaborate study on the heavy mineral composition of Neogene sediments in the southern North Sea Basin was done by Edelman \& Doeglas (1933). They recognized a marine A province to the northwest, characterized by a high garnet, epidote and amphibole content, and a continental B province to the southeast, characterized by ultrastable minerals, staurolite and aluminosilicate polymorphs, with a mixing zone $\mathrm{AB}$ in between (Fig. 2). This general model could later be confirmed by Tavernier (1943) and De Breuck (1959) based on data of 
Figure 1. Miocene and Pliocene chronostratigraphy of the study area. The NW - SE section in Belgium runs approximately from Antwerp in the NW to the Limburg Campine - Ruhr Valley Graben (RVG) boundary in the SE. The section for Germany and the Netherlands is a $\mathrm{SE}-\mathrm{NW}$ section through the Lower Rhine Embayment and Ruhr Valley Graben. $\mathrm{Pd}$ $=$ Poederlee Formation. The approximate position of the Mid Miocene Unconformity (MMU) is indicated. In white, the approximate position of the Maaseik core is indicated as well as the position of the $\mathrm{X}$ unit and its correlation with the Campine Basin as proposed in the current paper. Figure adapted from Verhaegen et al. (2019)

Figure 2. Visualization of the classic model of heavy mineral provinces for Paleogene and Neogene sands as defined by Edelman \& Doeglas (1933). $\mathrm{Br}=$ Breda, $\mathrm{A}=$ Antwerp $\mathrm{HOB}=$ Heist-op-den-Berg, $\mathrm{Aa}=$ Aarschot, $\mathrm{B}=$ Brussels $\mathrm{L}=$ Leuven, $\mathrm{H}=$ Hasselt, $\mathrm{M}$ $=$ Maastricht, $\mathrm{SFH}=$ South Flemish Hills, RVG $=$ Ruhr Valley Graben. The blue lines linked to the different formations indicate their southern limit. (Adapted from Edelman \& Doeglas, 1933).
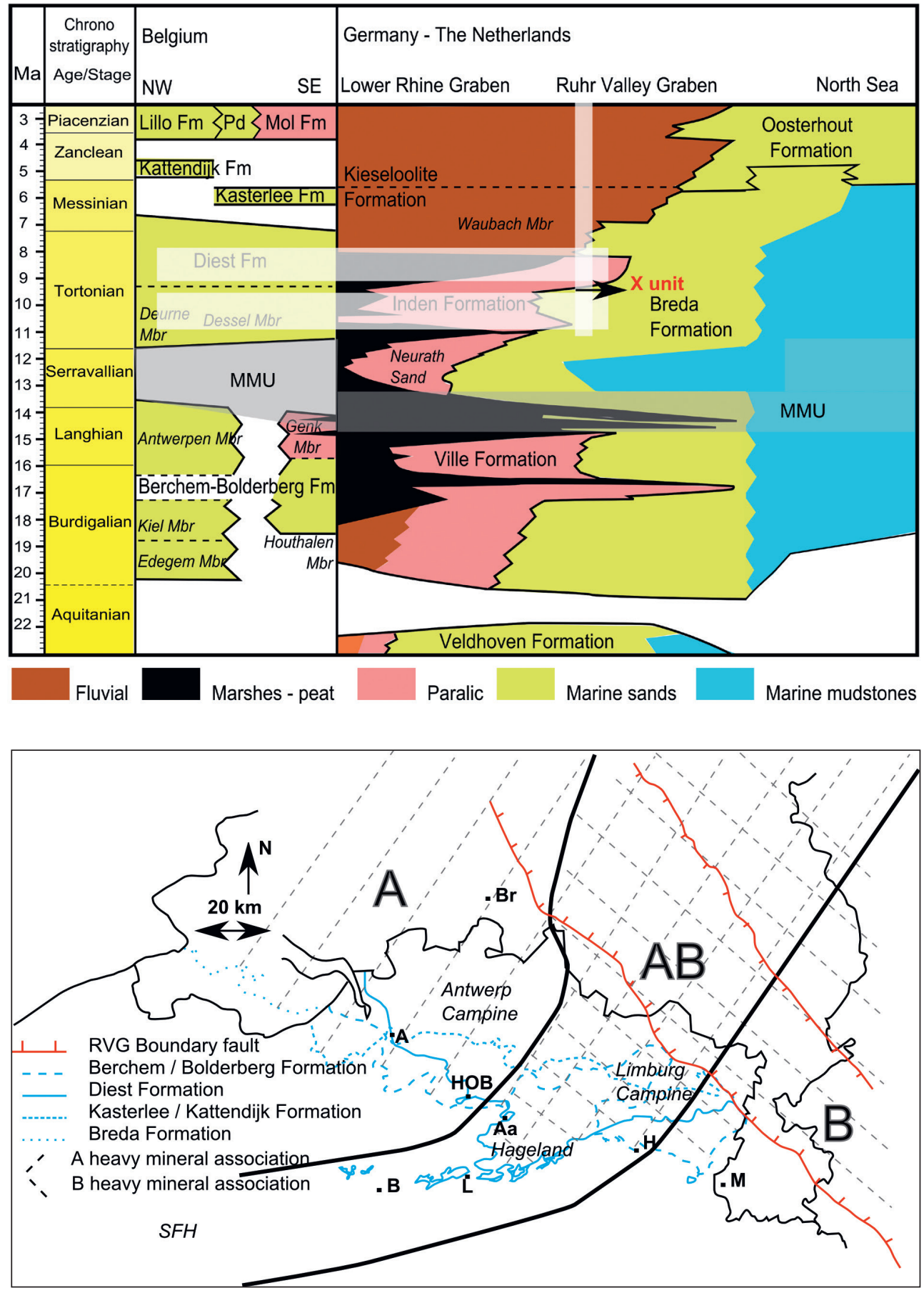

Belgian Neogene sediments. A large amount of literature data and unpublished data was collected by Verhaegen et al. (2019) and reanalyzed using advanced statistical techniques in order to extract more information from these classic datasets. The classic model by Edelman \& Doeglas (1933) could be confirmed using this statistical methodology and the evolution of sediment mixing in the Campine Basin throughout the Miocene could be defined in more detail. To summarize, there is a general increase in sediment input from the southern source through the Meuse-Rhine system throughout the Neogene. In the lower Miocene, the southern influence is only visible in the southeast of the Limburg Campine area and in the south of the RVG. In the upper Miocene to Pliocene the Rhine progrades much further north in the RVG and the southern influence reaches the central Campine Basin. The western Antwerp Campine area remains mostly influenced by the northern provenance throughout the Neogene. Upper Miocene to Pliocene sediments with a southern provenance signature are also affected by a higher degree of weathering, as well as sediments close to the surface such as those of the Hageland Hills and Flemish Hills.

\section{Materials and methods}

\subsection{Materials}

Belgian Neogene data used in Verhaegen et al. (2019) and also discussed in the current paper were collected from Geets \& De Breuck (1991) and Gullentops \& Huyghebaert (1999). These data consist of 626 heavy mineral counts spread out across the Campine Basin, Hageland Hills and Flemish Hills and throughout the Neogene (Fig. 3). These literature data and new data collected for the current study are not combined into one single dataset due to the differing methodology of heavy mineral counting, line counting versus ribbon counting, and due to the lower stratigraphic detail of the literature dataset. Both datasets are used for the interpretations while only the new data collected for the current study are discussed in detail.

In the current paper, data from 134 new samples is discussed, from 20 different boreholes and 8 outcrops (Fig. 3, Table 1). Core samples were collected at the Belgian Geological Survey in Brussels and ESV Euridice (NIRAS-ONDRAF) in Mol. The samples are distributed geographically across the entire study area 


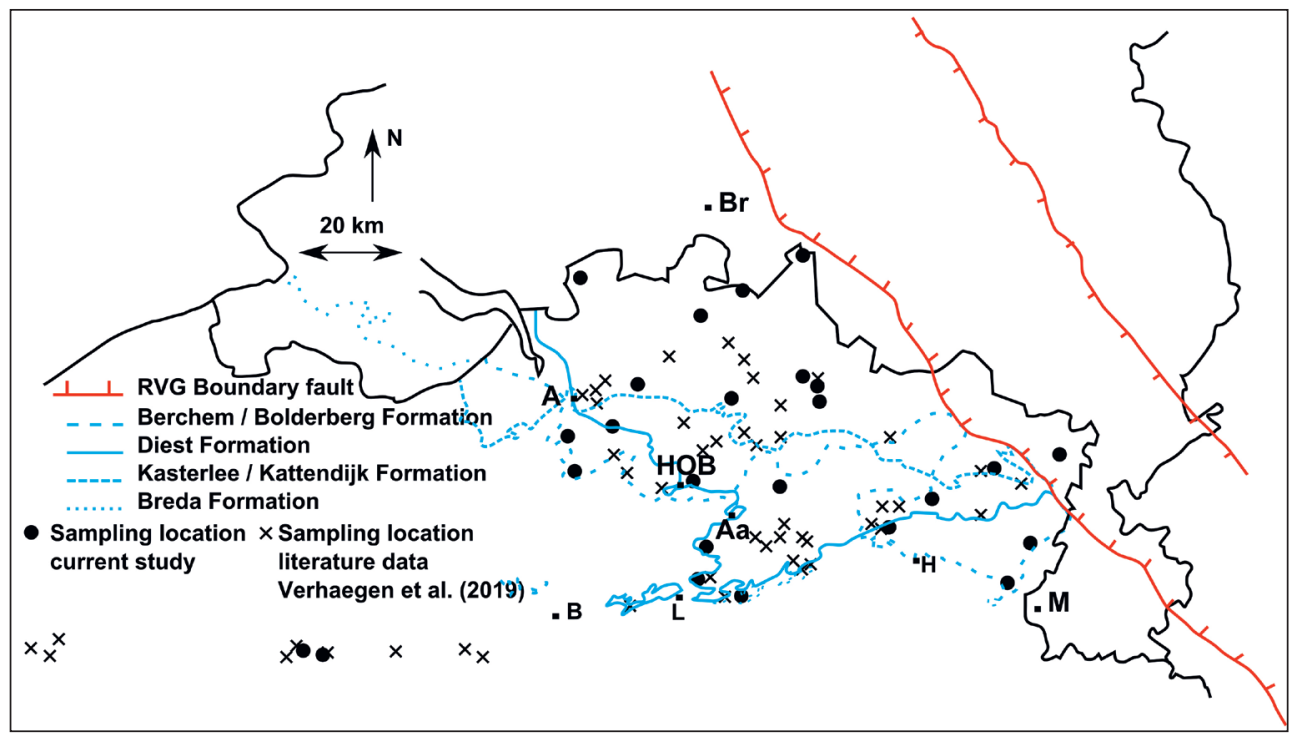

Figure 3. Locations of samples (from cores or outcrops) in the current study and from the literature data used in Verhaegen et al. (2019) which are referred to in the current study. The location of samples from literature is only an approximation. $\mathrm{Br}=$ Breda, $\mathrm{A}=$ Antwerp, $\mathrm{HOB}=$ Heistop-den-Berg, $\mathrm{Aa}=$ Aarschot, $\mathrm{B}=$ Brussels, $\mathrm{L}=$ Leuven, $\mathrm{H}=$ Hasselt, $\mathrm{M}=$ Maastricht, RVG $=$ Ruhr Valley Graben. The blue lines linked to the different formations indicate their southern limit.

Table 1. Sample database. DOV $=$ Database of the subsurface of Flanders (www.dov.vlaanderen.be). HOB $=$ Heist-op-den-Berg. Depth in $\mathrm{m}$. HM $=$ heavy mineral analysis, $\mathrm{GS}=$ grain size analysis, $\mathrm{Y}=$ yes, $\mathrm{N}=$ no. $\mathrm{AC}=$ Antwerp Campine, $\mathrm{LC}=$ Limburg Campine, Ha $=$ Hageland, Ant $=$ Antwerp, RVG = Ruhr Valley Graben, SFH = South Flemish Hills.

\begin{tabular}{|c|c|c|c|c|c|c|c|c|c|}
\hline NR & LOCATION & DOV CODE & NAME & REGION & DEPTH & FORMATION & MEMBER & HM & GS \\
\hline 1 & Kalmthout & kb7d6e-B239 & Kalmthout & $\mathrm{AC}$ & 82.5 & Diest & Diest & $\mathrm{Y}$ & $\mathrm{Y}$ \\
\hline 2 & Kalmthout & kb7d6e-B239 & Kalmthout & $\mathrm{AC}$ & 107.5 & Diest & Diest & Y & Y \\
\hline 3 & Kalmthout & kb7d6e-B239 & Kalmthout & $\mathrm{AC}$ & 112 & Berchem & Antwerpen & Y & Y \\
\hline 4 & Kalmthout & kb7d6e-B239 & Kalmthout & $\mathrm{AC}$ & 113.6 & Berchem & Antwerpen & Y & Y \\
\hline 5 & Kalmthout & kb7d6e-B239 & Kalmthout & $\mathrm{AC}$ & 116 & Berchem & Antwerpen / Kiel & Y & Y \\
\hline 6 & Kalmthout & kb7d6e-B239 & Kalmthout & $\mathrm{AC}$ & 119.5 & Berchem & Edegem / Kiel & Y & Y \\
\hline 7 & Kalmthout & kb7d6e-B239 & Kalmthout & $\mathrm{AC}$ & 132 & Berchem & Edegem & Y & $\mathrm{N}$ \\
\hline 8 & Veerle & kb24d60e-B219 & Veerle & $\mathrm{Ha}$ & 73 & Diest & Dessel & Y & Y \\
\hline 9 & Veerle & kb24d60e-B219 & Veerle & На & 82 & Diest & Dessel & Y & $\mathrm{N}$ \\
\hline 13 & Wijshagen & kb18d48w-B181 & Wijshagen & $\mathrm{LC}$ & 49 & Kasterlee & Kasterlee & Y & $\mathrm{N}$ \\
\hline 15 & Wijshagen & kb18d48w-B181 & Wijshagen & LC & 87 & Diest & Diest & Y & $\mathrm{N}$ \\
\hline 16 & Wijshagen & $\mathrm{kb} 18 \mathrm{~d} 48 \mathrm{w}-\mathrm{B} 181$ & Wijshagen & $\mathrm{LC}$ & 92.5 & Diest & Diest & Y & Y \\
\hline 17 & Wijshagen & kb18d48w-B181 & Wijshagen & $\mathrm{LC}$ & 97 & Bolderberg & Genk & Y & $\mathrm{N}$ \\
\hline 18 & Wijshagen & $\mathrm{kb} 18 \mathrm{~d} 48 \mathrm{w}-\mathrm{B} 181$ & Wijshagen & $\mathrm{LC}$ & 103 & Bolderberg & Houthalen & Y & $\mathrm{N}$ \\
\hline 19 & Wijshagen & kb18d48w-B181 & Wijshagen & $\mathrm{LC}$ & 131 & Bolderberg & Houthalen & Y & $\mathrm{Y}$ \\
\hline 20 & Wijshagen & kb18d48w-B181 & Wijshagen & $\mathrm{LC}$ & 138.5 & Bolderberg & Houthalen & $\mathrm{N}$ & Y \\
\hline 21 & Wijshagen & kb18d48w-B181 & Wijshagen & $\mathrm{LC}$ & 155 & Bolderberg & Houthalen & Y & Y \\
\hline 22 & Wijshagen & kb18d48w-B181 & Wijshagen & $\mathrm{LC}$ & 176.5 & Voort & Voort & Y & $\mathrm{N}$ \\
\hline 23 & Retie & kb17d31w-B228 & Retie & $\mathrm{AC}$ & 27.4 & Kasterlee & Kasterlee & Y & $\mathrm{N}$ \\
\hline 24 & Retie & kb17d31w-B228 & Retie & $\mathrm{AC}$ & 30.3 & Kasterlee & Kasterlee & Y & $\mathrm{N}$ \\
\hline 25 & Retie & kb17d31w-B228 & Retie & $\mathrm{AC}$ & 34.3 & Diest & Diest & Y & Y \\
\hline 26 & Retie & kb17d31w-B228 & Retie & $\mathrm{AC}$ & 100.3 & Diest & Diest & Y & Y \\
\hline 27 & Retie & kb17d31w-B228 & Retie & $\mathrm{AC}$ & 123.8 & Diest & Dessel & Y & $\mathrm{N}$ \\
\hline 28 & Retie & kb17d31w-B228 & Retie & $\mathrm{AC}$ & 134.3 & Diest & Dessel & Y & $\mathrm{Y}$ \\
\hline 29 & Retie & kb17d31w-B228 & Retie & $\mathrm{AC}$ & 136.3 & Berchem & Antwerpen & Y & $\mathrm{N}$ \\
\hline 31 & Retie & kb17d31w-B228 & Retie & $\mathrm{AC}$ & 141.3 & Berchem & Antwerpen & Y & $\mathrm{Y}$ \\
\hline 32 & Retie & kb17d31w-B228 & Retie & $\mathrm{AC}$ & 146.3 & Berchem & Edegem / Kiel & Y & Y \\
\hline 38 & Poederlee & kb16d30w-B315 & Poederlee & $\mathrm{AC}$ & 7.8 & Kasterlee & Kasterlee & Y & $\mathrm{N}$ \\
\hline 39 & Poederlee & kb16d30w-B315 & Poederlee & $\mathrm{AC}$ & 14.2 & Diest & Diest & Y & $\mathrm{N}$ \\
\hline 40 & Poederlee & kb16d30w-B315 & Poederlee & $\mathrm{AC}$ & 43.7 & Diest & Diest & $\mathrm{N}$ & $\mathrm{Y}$ \\
\hline 41 & Poederlee & kb16d30w-B315 & Poederlee & $\mathrm{AC}$ & 80.7 & Diest & Dessel & Y & Y \\
\hline 42 & Poederlee & kb16d30w-B315 & Poederlee & $\mathrm{AC}$ & 86.7 & Berchem & Antwerpen & Y & $\mathrm{N}$ \\
\hline 43 & Poederlee & kb16d30w-B315 & Poederlee & $\mathrm{AC}$ & 91.2 & Berchem & Kiel & $\mathrm{N}$ & Y \\
\hline
\end{tabular}




\begin{tabular}{|c|c|c|c|c|c|c|c|c|c|}
\hline NR & LOCATION & DOV CODE & NAME & REGION & DEPTH & FORMATION & MEMBER & HM & GS \\
\hline 44 & Poederlee & kb16d30w-B315 & Poederlee & $\mathrm{AC}$ & 93.2 & Berchem & Kiel & $\mathrm{Y}$ & $\mathrm{Y}$ \\
\hline 45 & Poederlee & kb16d30w-B315 & Poederlee & $\mathrm{AC}$ & 96.7 & Berchem & Edegem / Kiel & $\mathrm{N}$ & $\mathrm{Y}$ \\
\hline 46 & Poederlee & kb16d30w-B315 & Poederlee & $\mathrm{AC}$ & 100.7 & Berchem & Edegem & Y & $\mathrm{N}$ \\
\hline 49 & Rijkevorsel & kb8d16e-B37 & Rijkevorsel & $\mathrm{AC}$ & 77 & Diest & Diest & Y & $\mathrm{N}$ \\
\hline 51 & Rijkevorsel & kb8d16e-B37 & Rijkevorsel & $\mathrm{AC}$ & 115.3 & Diest & Dessel & Y & $\mathrm{N}$ \\
\hline 53 & Rijkevorsel & kb8d16e-B37 & Rijkevorsel & $\mathrm{AC}$ & 139.3 & Berchem & Antwerpen & $\mathrm{N}$ & $\mathrm{Y}$ \\
\hline 54 & Rijkevorsel & kb8d16e-B37 & Rijkevorsel & $\mathrm{AC}$ & 141.8 & Berchem & Antwerpen & Y & $\mathrm{Y}$ \\
\hline 55 & Rijkevorsel & kb8d16e-B37 & Rijkevorsel & $\mathrm{AC}$ & 144.8 & Berchem & Kiel & $\mathrm{Y}$ & $\mathrm{Y}$ \\
\hline 56 & Rijkevorsel & kb8d16e-B37 & Rijkevorsel & $\mathrm{AC}$ & 147.3 & Berchem & Edegem / Kiel & $\mathrm{N}$ & $\mathrm{Y}$ \\
\hline 57 & Rijkevorsel & kb8d16e-B37 & Rijkevorsel & $\mathrm{AC}$ & 150.8 & Berchem & Edegem & Y & $\mathrm{Y}$ \\
\hline 58 & Mol & kb17d31w-B212 & Mol & $\mathrm{AC}$ & 32.5 & Kasterlee & Kasterlee & Y & $\mathrm{Y}$ \\
\hline 59 & Mol & kb17d31w-B212 & Mol & $\mathrm{AC}$ & 39 & Diest & Diest & Y & $\mathrm{N}$ \\
\hline 60 & Mol & kb17d31w-B212 & Mol & $\mathrm{AC}$ & 53 & Diest & Diest & $\mathrm{N}$ & $\mathrm{Y}$ \\
\hline 61 & Mol & kb17d31w-B212 & Mol & $\mathrm{AC}$ & 105 & Diest & Diest & Y & $\mathrm{Y}$ \\
\hline 62 & Mol & kb17d31w-B212 & Mol & $\mathrm{AC}$ & 113 & Diest & Dessel & $\mathrm{N}$ & $\mathrm{Y}$ \\
\hline 63 & Mol & $\mathrm{kb} 17 \mathrm{~d} 31 \mathrm{w}-\mathrm{B} 212$ & Mol & $\mathrm{AC}$ & 121 & Diest & Dessel & Y & $\mathrm{N}$ \\
\hline 64 & Mol & kb17d31w-B212 & Mol & $\mathrm{AC}$ & 144 & Diest & Dessel & $\mathrm{Y}$ & $\mathrm{Y}$ \\
\hline 65 & Mol & kb17d31w-B212 & Mol & $\mathrm{AC}$ & 152.5 & Berchem & Antwerpen & Y & $\mathrm{Y}$ \\
\hline 66 & Mol & kb17d31w-B212 & Mol & $\mathrm{AC}$ & 157.5 & Berchem & Antwerpen & Y & $\mathrm{N}$ \\
\hline 67 & Mol & kb17d31w-B212 & Mol & $\mathrm{AC}$ & 163 & Voort & Voort & Y & $\mathrm{N}$ \\
\hline 68 & Maarle & kb3d4w-B55 & Maarle & $\mathrm{AC}$ & 146 & Kasterlee & Kasterlee & Y & $\mathrm{N}$ \\
\hline 69 & Maarle & kb3d4w-B55 & Maarle & $\mathrm{AC}$ & 190 & Diest & Diest & Y & $\mathrm{N}$ \\
\hline 82 & Houthalen & kb25d62e-B272 & Houthalen & $\mathrm{LC}$ & 105 & Bolderberg & Houthalen & $\mathrm{Y}$ & $\mathrm{N}$ \\
\hline 84 & Gellik & kb34d93e-B298 & Gellik & $\mathrm{LC}$ & 10 & Bolderberg & Genk & $\mathrm{Y}$ & $\mathrm{N}$ \\
\hline 85 & Gellik & kb34d93e-B298 & Gellik & $\mathrm{LC}$ & 13 & Bolderberg & Genk & Y & $\mathrm{N}$ \\
\hline 86 & Bolderberg & $\mathrm{kb} 25 \mathrm{~d} 62 \mathrm{w}-\mathrm{B} 270$ & Bolderberg & $\mathrm{LC}$ & 14.5 & Bolderberg & Genk & $\mathrm{Y}$ & $\mathrm{N}$ \\
\hline 87 & Bolderberg & $\mathrm{kb} 25 \mathrm{~d} 62 \mathrm{w}-\mathrm{B} 270$ & Bolderberg & $\mathrm{LC}$ & 24.5 & Bolderberg & Houthalen & $\mathrm{Y}$ & $\mathrm{N}$ \\
\hline 90 & Heist-op-den-Berg & kb24d59e-B154 & Heist-op-den-Berg & $\mathrm{AC}$ & 13 & Diest & Diest & Y & $\mathrm{Y}$ \\
\hline 92 & Heist-op-den-Berg & kb24d59e-B154 & Heist-op-den-Berg & $\mathrm{AC}$ & 23 & Berchem & Antwerpen & $\mathrm{Y}$ & $\mathrm{Y}$ \\
\hline 100 & Wilrijk & kb15d43w-B106 & Wilrijk & Ant & 3.5 & Berchem & Edegem & $\mathrm{Y}$ & $\mathrm{Y}$ \\
\hline 101 & Schilde & kb16d29w-B290 & Schilde & Ant & 17.5 & Diest & Diest & Y & $\mathrm{Y}$ \\
\hline 102 & Schilde & kb16d29w-B290 & Schilde & Ant & 20.5 & Diest & Diest & Y & $\mathrm{Y}$ \\
\hline 103 & Schilde & kb16d29w-B290 & Schilde & Ant & 56 & Berchem & Antwerpen & Y & $\mathrm{Y}$ \\
\hline 104 & Schilde & kb16d29w-B290 & Schilde & Ant & 62.5 & Berchem & Antwerpen & $\mathrm{N}$ & $\mathrm{Y}$ \\
\hline 105 & Schilde & kb16d29w-B290 & Schilde & Ant & 64.5 & Berchem & Kiel & $\mathrm{N}$ & $\mathrm{Y}$ \\
\hline 106 & Schilde & kb16d29w-B290 & Schilde & Ant & 67.5 & Berchem & Kiel & Y & $\mathrm{Y}$ \\
\hline 107 & Schilde & kb16d29w-B290 & Schilde & Ant & 69.5 & Berchem & Edegem & Y & $\mathrm{Y}$ \\
\hline 111 & Maaseik & $\mathrm{kb} 18 \mathrm{~d} 49 \mathrm{w}-\mathrm{B} 220$ & Maaseik & RVG & 185.5 & Kieseloolite & Waubach & $\mathrm{Y}$ & $\mathrm{Y}$ \\
\hline 112 & Maaseik & $\mathrm{kb} 18 \mathrm{~d} 49 \mathrm{w}-\mathrm{B} 220$ & Maaseik & RVG & 195.5 & Breda & $X^{\prime}$ & Y & $\mathrm{Y}$ \\
\hline 113 & Maaseik & $\mathrm{kb} 18 \mathrm{~d} 49 \mathrm{w}-\mathrm{B} 220$ & Maaseik & RVG & 230 & Breda & Breda-Deurne & Y & $\mathrm{Y}$ \\
\hline 114 & Maaseik & $\mathrm{kb} 18 \mathrm{~d} 49 \mathrm{w}-\mathrm{B} 220$ & Maaseik & RVG & 240 & Breda & Breda-non & $\mathrm{Y}$ & $\mathrm{Y}$ \\
\hline 115 & Maaseik & kb18d49w-B220 & Maaseik & RVG & 270 & Breda & Breda-non & Y & $\mathrm{Y}$ \\
\hline 116 & Maaseik & $\mathrm{kb} 18 \mathrm{~d} 49 \mathrm{w}-\mathrm{B} 220$ & Maaseik & RVG & 280 & Breda & Breda-Antwerpen & Y & $\mathrm{Y}$ \\
\hline 117 & Maaseik & $\mathrm{kb} 18 \mathrm{~d} 49 \mathrm{w}-\mathrm{B} 220$ & Maaseik & RVG & 153 & Kieseloolite & Waubach & $\mathrm{Y}$ & $\mathrm{Y}$ \\
\hline 118 & Maaseik & $\mathrm{kb} 18 \mathrm{~d} 49 \mathrm{w}-\mathrm{B} 220$ & Maaseik & RVG & 200 & Breda & Breda-Deurne & Y & $\mathrm{Y}$ \\
\hline 119 & Maaseik & $\mathrm{kb} 18 \mathrm{~d} 49 \mathrm{w}-\mathrm{B} 220$ & Maaseik & RVG & 257 & Breda & Beda-non & $\mathrm{N}$ & $\mathrm{Y}$ \\
\hline 120 & Maaseik & $\mathrm{kb} 18 \mathrm{~d} 49 \mathrm{w}-\mathrm{B} 220$ & Maaseik & RVG & 299 & Breda & Breda-Antwerpen & Y & $\mathrm{Y}$ \\
\hline MA1 & Maaseik & kb18d49w-B220 & Maaseik & RVG & 191.5 & Kieseloolite & Waubach & Y & $\mathrm{N}$ \\
\hline MA2 & Maaseik & kb18d49w-B220 & Maaseik & RVG & 194.5 & Breda & $X^{\prime}$ & Y & $\mathrm{N}$ \\
\hline MA3 & Maaseik & $\mathrm{kb} 18 \mathrm{~d} 49 \mathrm{w}-\mathrm{B} 220$ & Maaseik & RVG & 195.5 & Breda & $X^{\prime}$ & Y & $\mathrm{N}$ \\
\hline MA4 & Maaseik & kb18d49w-B220 & Maaseik & RVG & 196.5 & Breda & $X^{\prime}$ & Y & $\mathrm{N}$ \\
\hline MA5 & Maaseik & kb18d49w-B220 & Maaseik & RVG & 202.5 & Breda & Breda-Deurne & $\mathrm{Y}$ & $\mathrm{N}$ \\
\hline
\end{tabular}




\begin{tabular}{|c|c|c|c|c|c|c|c|c|c|}
\hline NR & LOCATION & DOV CODE & NAME & REGION & DEPTH & FORMATION & MEMBER & HM & GS \\
\hline 121 & Baarle-Hertog & kb8d8w-B19 & Baarle-Hertog & $\mathrm{AC}$ & 172 & Diest & Dessel & $\mathrm{Y}$ & $\mathrm{Y}$ \\
\hline 122 & Baarle-Hertog & kb8d8w-B19 & Baarle-Hertog & $\mathrm{AC}$ & 180 & Diest & Dessel & Y & $\mathrm{Y}$ \\
\hline 123 & Baarle-Hertog & kb8d8w-B19 & Baarle-Hertog & $\mathrm{AC}$ & 184 & Berchem & Antwerpen & $\mathrm{Y}$ & $\mathrm{Y}$ \\
\hline 124 & Baarle-Hertog & kb8d8w-B19 & Baarle-Hertog & $\mathrm{AC}$ & 188 & Berchem & Antwerpen & $\mathrm{N}$ & $\mathrm{Y}$ \\
\hline 125 & Baarle-Hertog & kb8d8w-B19 & Baarle-Hertog & $\mathrm{AC}$ & 212 & Berchem & Antwerpen & $\mathrm{Y}$ & $\mathrm{Y}$ \\
\hline 126 & Boechout & kb15d43e-B223 & Boechout & Ant & 22 & Berchem & Antwerpen & $\mathrm{Y}$ & $\mathrm{Y}$ \\
\hline 127 & Boechout & kb15d43e-B223 & Boechout & Ant & 25 & Berchem & Kiel & $\mathrm{Y}$ & $\mathrm{Y}$ \\
\hline 128 & Boechout & kb15d43e-B223 & Boechout & Ant & 27 & Berchem & Edegem & $\mathrm{Y}$ & $\mathrm{Y}$ \\
\hline 129 & Boechout & kb15d43e-B223 & Boechout & Ant & 29 & Berchem & Edegem & $\mathrm{N}$ & $\mathrm{Y}$ \\
\hline 130 & Boechout & kb15d43e-B223 & Boechout & Ant & 18 & Berchem & Antwerpen & $\mathrm{N}$ & $\mathrm{Y}$ \\
\hline 131 & Rumst & TO-20160916 & Rumst & $\mathrm{AC}$ & outcrop & Berchem & Edegem & $\mathrm{Y}$ & $\mathrm{Y}$ \\
\hline 132 & Rumst & TO-20160916 & Rumst & $\mathrm{AC}$ & outcrop & Berchem & Edegem & $\mathrm{Y}$ & $\mathrm{N}$ \\
\hline 134 & Dessel & BGD031W0370 & ON-Dessel-5 & $\mathrm{AC}$ & 90.4 & Diest & Diest & $\mathrm{N}$ & $\mathrm{Y}$ \\
\hline 135 & Dessel & BGD031W0370 & ON-Dessel-5 & $\mathrm{AC}$ & 105 & Diest & Diest & $\mathrm{Y}$ & $\mathrm{Y}$ \\
\hline 136 & Dessel & BGD031W0370 & ON-Dessel-5 & $\mathrm{AC}$ & 116 & Diest & Diest & $\mathrm{Y}$ & $\mathrm{Y}$ \\
\hline 137 & Dessel & BGD031W0370 & ON-Dessel-5 & $\mathrm{AC}$ & 130 & Diest & Dessel & $\mathrm{N}$ & $\mathrm{Y}$ \\
\hline 138 & Dessel & BGD031W0370 & ON-Dessel-5 & $\mathrm{AC}$ & 138 & Diest & Dessel & $\mathrm{Y}$ & $\mathrm{Y}$ \\
\hline 139 & Dessel & BGD031W0370 & ON-Dessel-5 & $\mathrm{AC}$ & 144 & Berchem & Antwerpen & $\mathrm{N}$ & $\mathrm{Y}$ \\
\hline 140 & Dessel & BGD031W0370 & ON-Dessel-5 & $\mathrm{AC}$ & 145 & Berchem & Antwerpen & $\mathrm{Y}$ & $\mathrm{Y}$ \\
\hline 141 & Dessel & BGD031W0370 & ON-Dessel-5 & $\mathrm{AC}$ & 158.7 & Berchem & Antwerpen & $\mathrm{Y}$ & $\mathrm{Y}$ \\
\hline 142 & Dessel & BGD031W0370 & ON-Dessel-5 & $\mathrm{AC}$ & 163.5 & Voort & & $\mathrm{Y}$ & $\mathrm{Y}$ \\
\hline 143 & Dessel & kb17d31w-B299 & ON-Dessel-2 & $\mathrm{AC}$ & 6.5 & Mol & upper Mol & $\mathrm{Y}$ & $\mathrm{Y}$ \\
\hline 144 & Dessel & kb17d31w-B299 & ON-Dessel-2 & $\mathrm{AC}$ & 9.5 & Mol & lower Mol & $\mathrm{N}$ & $\mathrm{Y}$ \\
\hline 145 & Dessel & kb17d31w-B299 & ON-Dessel-2 & $\mathrm{AC}$ & 13.5 & Mol & lower Mol & $\mathrm{Y}$ & $\mathrm{Y}$ \\
\hline 146 & Dessel & kb17d31w-B299 & ON-Dessel-2 & $\mathrm{AC}$ & 21 & Mol & lower Mol & $\mathrm{N}$ & $\mathrm{Y}$ \\
\hline 147 & Dessel & kb17d31w-B299 & ON-Dessel-2 & $\mathrm{AC}$ & 24.5 & Kasterlee & & $\mathrm{Y}$ & $\mathrm{Y}$ \\
\hline 148 & Dessel & kb17d31w-B299 & ON-Dessel-2 & $\mathrm{AC}$ & 28.2 & Kasterlee & & $\mathrm{N}$ & $\mathrm{Y}$ \\
\hline 149 & Dessel & kb17d31w-B299 & ON-Dessel-2 & $\mathrm{AC}$ & 31.5 & Kasterlee & & $\mathrm{Y}$ & $\mathrm{Y}$ \\
\hline 150 & Dessel & kb17d31w-B299 & ON-Dessel-2 & $\mathrm{AC}$ & 33.5 & Kasterlee & & $\mathrm{Y}$ & $\mathrm{Y}$ \\
\hline 151 & Dessel & kb17d31w-B299 & ON-Dessel-2 & $\mathrm{AC}$ & 35.5 & Diest & Diest & $\mathrm{N}$ & $\mathrm{Y}$ \\
\hline 152 & Dessel & kb17d31w-B299 & ON-Dessel-2 & $\mathrm{AC}$ & 49.5 & Diest & Diest & $\mathrm{N}$ & $\mathrm{Y}$ \\
\hline 153 & Heist-op-den-Berg & TO-20140919 & HOB outcrop & $\mathrm{AC}$ & outcrop & Diest & Diest & $\mathrm{Y}$ & $\mathrm{N}$ \\
\hline 154 & Heist-op-den-Berg & TO-20140919 & HOB outcrop & $\mathrm{AC}$ & outcrop & Kasterlee & Hallaar & $\mathrm{Y}$ & $\mathrm{N}$ \\
\hline 155 & Heist-op-den-Berg & TO-20140919 & HOB outcrop & $\mathrm{AC}$ & outcrop & Kasterlee & Beerzel & $\mathrm{Y}$ & $\mathrm{N}$ \\
\hline 156 & Heist-op-den-Berg & TO-20140919 & HOB outcrop & $\mathrm{AC}$ & outcrop & Kasterlee & Heist-o/d-Berg & $\mathrm{Y}$ & $\mathrm{N}$ \\
\hline 157 & Kesselberg & TO-20161025 & Kesselberg & $\mathrm{Ha}$ & outcrop & Diest & Diest & $\mathrm{Y}$ & $\mathrm{Y}$ \\
\hline 158 & Kesselberg & TO-20161025 & Kesselberg & $\mathrm{Ha}$ & outcrop & Diest & Diest & $\mathrm{Y}$ & $\mathrm{Y}$ \\
\hline 159 & Kesselberg & TO-20161025 & Kesselberg & $\mathrm{Ha}$ & outcrop & Diest & Diest & $\mathrm{Y}$ & $\mathrm{Y}$ \\
\hline 160 & Wijngaardberg & TO-20161025B & Wijngaardberg & $\mathrm{Ha}$ & outcrop & Diest & Diest & $\mathrm{Y}$ & $\mathrm{Y}$ \\
\hline 189 & Opgrimbie & TO-20170329 & Opgrimbie & $\mathrm{LC}$ & outcrop & Bolderberg & $\begin{array}{l}\text { Genk } \\
\text { (Opgrimbie facies) }\end{array}$ & $\mathrm{Y}$ & $\mathrm{Y}$ \\
\hline 190 & Lubbeek & TO-20171107 & Pellenberg & $\mathrm{Ha}$ & outcrop & Bolderberg & Houthalen & $\mathrm{Y}$ & $\mathrm{N}$ \\
\hline 191 & Lubbeek & TO-20171107 & Pellenberg & На & outcrop & Bolderberg & Houthalen & $\mathrm{Y}$ & $\mathrm{N}$ \\
\hline LJ03 & Muziekberg & TO-20140501 & Muziekberg & SFH & outcrop & $?$ & $?$ & $\mathrm{Y}$ & $\mathrm{Y}$ \\
\hline LJ06 & Muziekberg & TO-20140501 & Muziekberg & SFH & outcrop & $?$ & $?$ & $\mathrm{Y}$ & $\mathrm{Y}$ \\
\hline LJ10 & Muziekberg & TO-20140501 & Muziekberg & SFH & outcrop & $?$ & $?$ & $\mathrm{Y}$ & $\mathrm{Y}$ \\
\hline LJ14 & Muziekberg & TO-20140501 & Muziekberg & SFH & outcrop & $?$ & $?$ & $\mathrm{Y}$ & $\mathrm{Y}$ \\
\hline LJ21 & Pottelberg & TO-20140501B & Pottelberg & SFH & outcrop & $?$ & $?$ & $\mathrm{Y}$ & $\mathrm{Y}$ \\
\hline LJ22 & Pottelberg & TO-20140501B & Pottelberg & SFH & outcrop & $?$ & $?$ & $\mathrm{Y}$ & $\mathrm{Y}$ \\
\hline LJ23 & Pottelberg & TO-20140501B & Pottelberg & SFH & outcrop & $?$ & $?$ & $\mathrm{Y}$ & $\mathrm{Y}$ \\
\hline
\end{tabular}


and stratigraphically throughout the entire Miocene, with some Pliocene samples. Borehole samples are from cored sections.

Samples of the Kasterlee Formation are classified using the current working definition of the Kasterlee Formation, as discussed above in Section 2. A distinction is made in the discussion of the results between the Kasterlee-sensu-Gulinck unit, which possibly belongs to the Pliocene Mol Formation, and the clayey Kasterlee unit. Samples from outcrops were taken from fresh surfaces if possible. The samples from the Wienerberger quarry in Rumst are samples of the lower Miocene Edegem Sand which lies directly on top of the Oligocene Boom clay excavated in this quarry. Hageland Diest sand was sampled from the Kesselberg and Wijngaardberg outcrops (exact location through DOV-code in Table 1). The lowest sample at Kesselberg is situated directly on top of the unconformity with a thick base gravel and overlying lower Oligocene sediments. Two other samples at the Kesselberg are from two different intervals of softer sediment in between the hard Diest iron sandstone beds which accentuate the large cross beds. The sample from Wijngaardberg is from a less fresh surface in an iron sandstone bed. The samples from the Heist-opden-Berg outcrop are from the top of the Heist-op-den-Berg hill where an outcrop of Diest Sand and Kasterlee Sand with three distinct units is present (Verhaegen et al., 2014; Verhaegen et al., 2020, this volume). The sample from the Pellenberg quarry in Lubbeek is of the lower-middle Miocene Houthalen Sand, which lies on top of the Boom clay at that location, with a coarse gravel at its base. The sample from Opgrimbie is taken in the abandoned Sibelco quarry Kikbeekbron. It is a sample of the middle Miocene Opgrimbie facies of the Genk Member, taken just above a lignite layer. Finally, in the Flemish Hills Pottelberg and Muziekberg outcrops, samples were taken of the sediment classically described as Diest Formation but reclassified as the Flemish Hills 'formation' by Houthuys (2014). This unit is subdivided into lower bioturbated beds, middle pebbly beds and upper glauconiferous beds following Houthuys (2014), and this subdivision will be used further to describe results for this unit.

\subsection{Heavy mineral analysis}

In total, conventional heavy mineral analysis was carried out on 112 samples. A standard sample preparation was done, as described in Mange \& Maurer (1992), on about $100 \mathrm{~g}$ of bulk sediment for each sample. Since heavy mineral analysis was performed on the fraction $>63 \mu \mathrm{m}$, the samples were first wet sieved at $63 \mu \mathrm{m}$. Both the fraction $>63 \mu \mathrm{m}$ and $<63 \mu \mathrm{m}$ were retrieved and weighed. There was no upper grain size limit, yet only very few heavy mineral grains in the coarsest samples exceeded $500 \mu \mathrm{m}$ and most grains were $<250 \mu \mathrm{m}$. Afterwards, samples were treated with $10 \%$ $(1.2 \mathrm{~N}) \mathrm{HCl}$ to remove carbonate and iron coatings. The samples were left in boiling $10 \% \mathrm{HCl}$ for maximum five to ten minutes, to limit the acid corrosion of the heavy mineral grains. The mineral apatite is strongly affected during this process. Though previous research indicates apatite is not a significant heavy mineral in the studied sediments (Edelman \& Doeglas, 1933; Geets \& De Breuck, 1991). The separation of the heavy minerals and the mounting of the grains were carried out at the mineral separation laboratory of the VU Amsterdam (University of Amsterdam). Heavy minerals were separated from the bulk sediment using a liquid mixture of diiodomethane and dichlorobenzene with a density of $2.89 \mathrm{~g} /$ $\mathrm{cm}^{3}$, equal to the density of bromoform which was classically used for heavy mineral separation. In this approach, the heavy mineral grains are separated in a beaker which sits in the center of a centrifuge, whereby the light mineral fraction (density $<2.89$ $\mathrm{g} / \mathrm{cm}^{3}$ ) exits the beaker through overflow during rotation. Only the heavy fraction was retrieved due to time constraints. Both the weight of the samples prior to heavy mineral separation and the weight of the heavy mineral separates were measured, in order to calculate the total heavy mineral content (HMC) of the samples. Subsequently, the heavy mineral grains were mounted on glass plates for optical microscopy, using Canada balsam. Conventional heavy mineral analysis was performed with an Olympus polarizing microscope using Mange \& Maurer (1992) as a guideline for mineral identification. Two hundred transparent heavy minerals were counted per slide using the ribbon counting method, unless not enough transparent heavy minerals were present on a slide which was the case for 26 of the counted samples, of which for seven samples less than 100 grains were counted. Opaque heavy minerals were counted as one group. The twelve transparent heavy mineral groups distinguished are zircon, Ti-group minerals (mainly rutile, sporadically anatase and brookite), tourmaline, staurolite, kyanite, andalusite, sillimanite, garnet, epidote-group minerals (mainly epidote, but also (clino)zoisite), hornblende, other inosilicates (mainly amphiboles other than hornblende) and accessory minerals (including for example sphene, spinel, corundum and unidentified grains). As the Ti-group minerals are dominated by rutile, this group will be referred to as rutile in the remainder of the text.

\subsection{Grain size analysis}

Grain size analysis was done for 94 samples of which 72 samples were also analyzed for heavy mineral content. Sample preparation carried out for grain size analysis was very similar to sample preparation for heavy mineral analysis. About $10 \mathrm{~g}$ of bulk sediment was analyzed for each sample. Samples were treated with $10 \% \mathrm{HCl}$ until all carbonate, from fossil shells and grain coatings, was removed. Next, the samples were boiled in $10 \% \mathrm{HCl}$ up to 10 minutes to remove iron coatings. Samples were then washed twice with distilled water in a centrifuge. In many studies, samples are also treated with hydrogen peroxide to remove organic material. That step could be skipped in this case for all samples, except a few from the Bolderberg Formation, since no organic material is present. Prior to measurement, the prepared samples were subjected to an ultrasonic rod. Grain size analyses itself were carried out using a laser-diffraction particle sizer at the department of Earth and Environmental Sciences of the KU Leuven (Beckman Coulter LS 13 320), measuring grain size between 0.05 and $1000 \mu \mathrm{m}$.

\subsection{Statistical methods}

Cumulative diagrams, in the form of pie charts, are presented in order to visualize the raw heavy mineral data averaged for each defined unit, while the grain size data are visualized on distribution plots for each measured sample and grouped for each defined unit. Following the workflow proposed in Verhaegen et al. (2019), the heavy mineral data are analyzed through principal component analysis (PCA) after centered log-ratio transformation (CLR). Compositional data cannot be analyzed correctly with classical (multivariate) statistical methods due to their constant sum property and non-negativity, which is mitigated by applying CLR (Aitchison, 1986). Based on the PCA, log-ratio plots are made to visualize the variation in heavy mineral composition. The logratio plots have the advantage of a quick objective comparison between different units, visualizing differences and similarities between units and variation within units. Furthermore, new data can be easily added to these plots (Verhaegen et al., 2019).

\section{Results}

\subsection{Heavy mineral composition and grain size per unit}

The Neogene sediments studied have a strongly variable grain size distribution, ranging from very fine to coarse, poorly to wellsorted and clay-poor to clay-rich sand. The samples examined for this study have a non-diverse heavy mineral assemblage rich in ultrastable minerals and lacking less stable minerals such as pyroxenes or more rare components such as spinel or sphene. There is no clear break between different samples or sections and there are no rare components which occur exclusively in certain units. The most diverse heavy mineral assemblages, with a large portion of epidote group minerals, amphiboles and garnet can mainly be found in samples of the northern part of the basin and the lower part of the stratigraphic column. To assess the variability in more detail, the grain size distribution and heavy mineral assemblage of different units are discussed next for each defined period and region. The heavy mineral results are visualized in pie charts as average compositions for each defined group, yet the range of values is also discussed in the results.

\subsubsection{Lower-middle Miocene}

a) Antwerp Campine

The different members of the Berchem Formation have a slightly different grain size distribution. The Edegem Member 


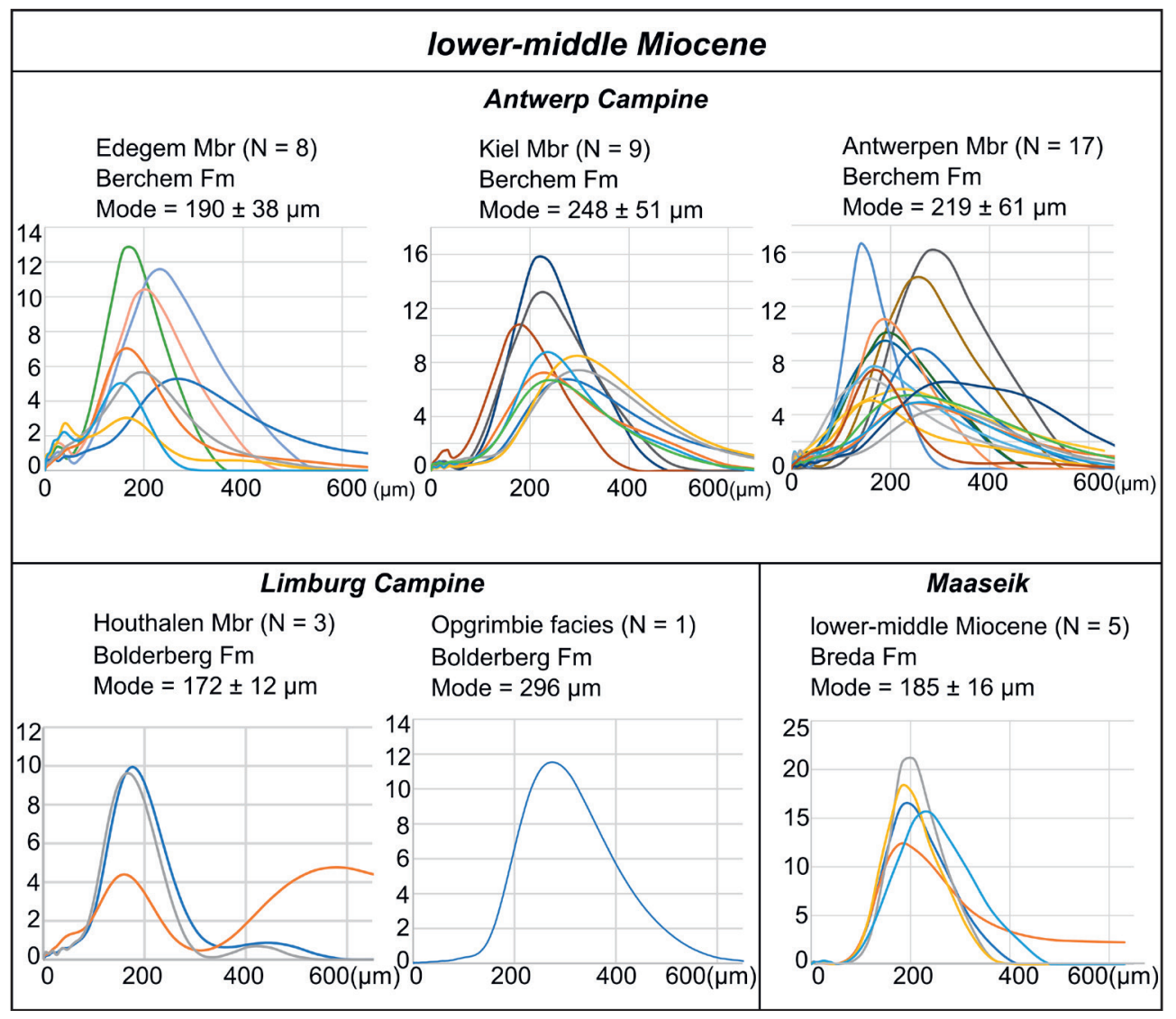

Figure 4. Grain size distribution curves for all samples of the lower-middle Miocene, separated per member or formation. The number of samples analyzed per unit $(\mathrm{N})$ and the modal grain size and standard deviation of the modal grain size based on the measured samples are given. Different colors are used to distinguish between different samples on each plot.

is generally a well-sorted clay-rich fine sand, according to the Wentworth (1922) grain size classification, with a modal grain size of $190 \pm 38 \mu \mathrm{m}$, based on the samples analyzed for this study. The overlying Kiel Member has the coarsest average modal grain size of the Berchem Formation with a modal grain size of 248 $\pm 51 \mu \mathrm{m}$. The grain size distribution of the Antwerpen Member is strongly variable between different samples, but the average modal grain size is $219 \pm 61 \mu \mathrm{m}$, ranging from well-sorted to poorly sorted (Fig. 4). The heavy mineral assemblage of the Berchem Formation is mostly consistent between the different members. The combined percentage of epidote and amphiboles ranges from 8 to $62 \%$ with an average of $31 \%$. This is slightly lower in the Edegem (28\%) and Kiel (27\%) Members and slightly higher in the Antwerpen Member (36\%). The garnet content is also high, ranging from 12 to $52 \%$ with an average of $25 \%$. The average garnet content is a bit higher in the Kiel Member (29\%) and a bit lower in the Edegem Member (23\%). Tourmaline and the metamorphic minerals (aluminosilicate polymorphs and staurolite) represent 5 to $23 \%$ of the heavy mineral assemblage, with an average of $13 \%$. This is slightly lower in the Edegem and Antwerpen Members (12\%) and higher in the Kiel Member $(15 \%)$. Finally, the ultrastable minerals zircon and rutile and rare accessory minerals represent 15 to $49 \%$ of the composition with an average of $30 \%$, with the highest values in the Edegem Member (35\%) followed by the Kiel Member (32\%) and the Antwerpen Member (27\%) (Fig. 5). The described differences between the members are only subtle and not significant as the variation within members is much larger than the variation between members.

b) Limburg Campine

The Houthalen Member of the Bolderberg Formation is well sorted and fine-grained with a modal grain size of $172 \pm 12$ $\mu \mathrm{m}$. One of the measured samples has a coarse second mode of $590 \mu \mathrm{m}$. The grain size distribution of the Genk Member was not measured, except for one sample of the Opgrimbie facies. This sample is well sorted and medium-grained with a modal grain size of $296 \mu \mathrm{m}$ (Fig. 4). The heavy mineral composition of the Houthalen and Genk Members is rather similar, dominated by zircon and rutile, but very different from the Opgrimbie facies which has a very low proportion of zircon and rutile and is dominated by tourmaline and the metamorphic minerals
(Fig. 5). Heavy mineral analyses by Gullentops (1963, 1973) on the Opgrimbie facies confirm the exceptionally high content of tourmaline and metamorphic minerals observed in the single sample analyzed in the current study, though there is also an upper layer present which is strongly enriched in zircon. The Houthalen Member contains 4 to $25 \%$ of epidote and amphibole, with an average of $16 \%$. Garnet accounts for 2 to $15 \%$ with an average of $8 \%$. Tourmaline and the metamorphic minerals make up 8 to $34 \%$ of the heavy mineral composition, with an average of $20 \%$. The percentage of zircon and rutile ranges from $34 \%$ to $84 \%$ with an average of $56 \%$. In the Genk Member, epidote and amphiboles make up 4 to $24 \%$ of the heavy mineral assemblage, with an average of $9 \%$. The garnet percentage is 0 to $21 \%$, with an average of $7 \%$. Tourmaline and the metamorphic minerals account for 4 to $49 \%$ with an average of $26 \%$. The percentage of zircon and rutile ranges from 40 to $88 \%$, averaging $59 \%$. Finally, in the sample of the Opgrimbie facies, no epidote or amphibole nor garnet was observed. Tourmaline and the metamorphic minerals make up $83 \%$ of the sample, which includes $10 \%$ andalusite and $6 \%$ sillimanite. Zircon and rutile account for $16 \%$ of the heavy mineral composition.

c) Hageland

On some of the Hageland Hills, the Houthalen Member is preserved underneath the Diest Formation. The grain size distribution of the Houthalen Member was not measured. Based on two samples, epidote and amphibole account for $19 \%$ of the heavy mineral composition, which is almost exclusively due to a higher epidote percentage (18\%). The percentage of garnet is $22 \%$. Tourmaline and the metamorphic minerals make up $17 \%$ of the heavy mineral assemblage. The percentage of zircon and rutile is $42 \%$ (Fig. 5 ).

d) Southern Ruhr Valley Graben (Maaseik)

In the southern RVG, the lower-middle Miocene sediments are well-sorted fine-grained sand with a modal grain size of 185 $\pm 16 \mu \mathrm{m}$ (Fig. 4). The lower-middle Miocene sediments have 24 to $49 \%$ of epidote and amphibole, with an average of $39 \%$. The garnet percentage is 14 to $21 \%$ with an average of $17 \%$. Tourmaline and the metamorphic minerals account for 13 to $21 \%$ of the heavy mineral composition, with an average of $18 \%$. The zircon and rutile percentage ranges from 14 to $42 \%$, with an average of $26 \%$ (Fig. 5). 
Figure 5. Pie charts of the heavy mineral composition for all samples of the lower-middle Miocene, separated per member or formation. The number of samples analyzed per unit $(\mathrm{N})$ is given. The mineral groups which are related to a northern provenance, according to the results of Verhaegen et al. (2019), are delineated with blue line. The mineral groups which are related to a southern provenance are delineated with a red line. $\mathrm{Zrn}=$ zircon, Ti-group = titanium-group minerals (mainly rutile), Other $=$ accessory minerals, Tur $=$ tourmaline, $\mathrm{Ky}$ = kyanite, And = andalusite, Sil $=$ sillimanite, $\mathrm{St}=$ staurolite, Grt = garnet, Ep-group = epidote-group minerals (mainly epidote and clinozoisite), $\mathrm{Hbl}=$ hornblende.

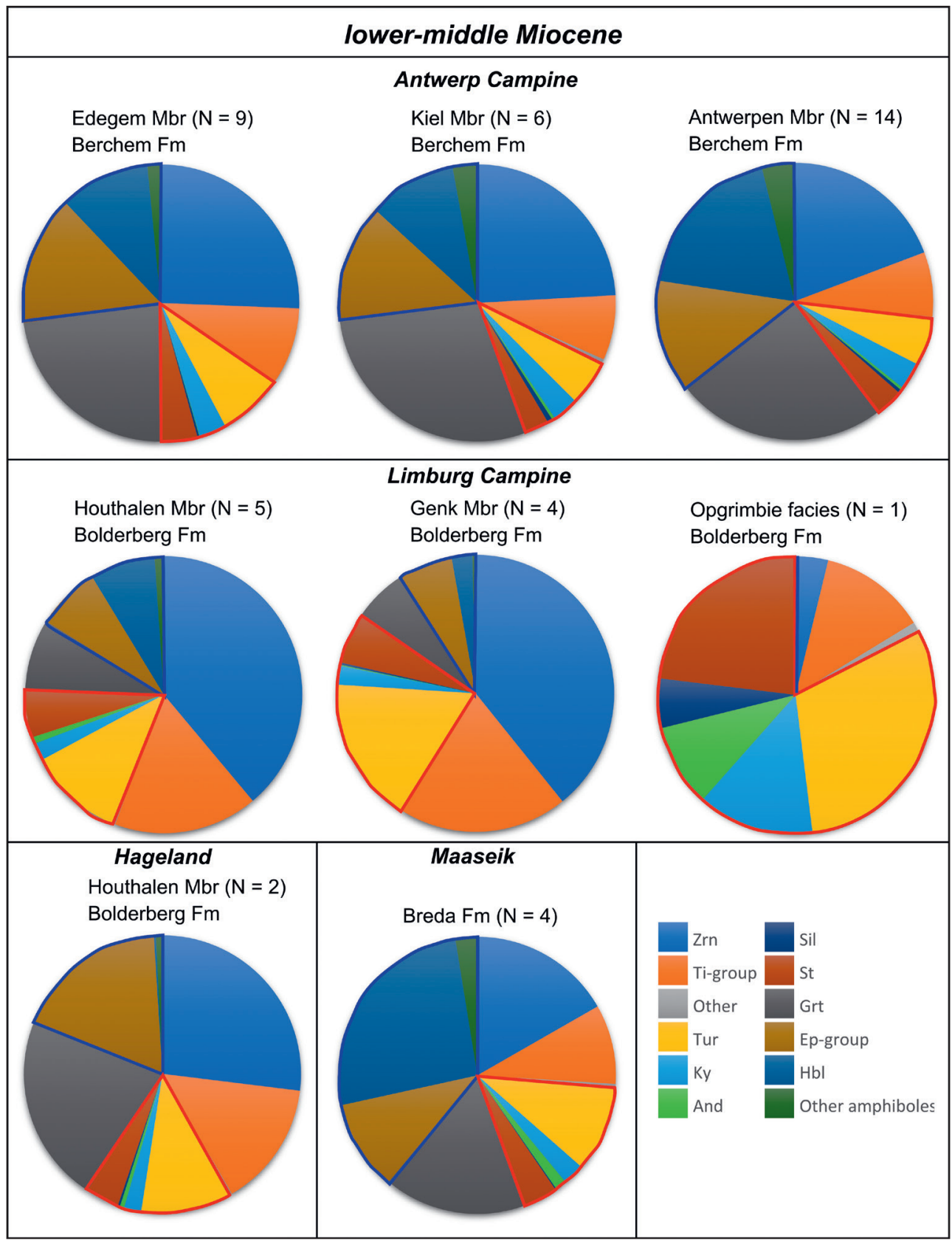

\subsubsection{Tortonian}

a) Antwerp Campine

In the Diest Formation, there is a clear difference in grain size distribution between the Dessel Member and the bulk of the Diest Formation sand above (for practical reasons further described here as Diest 'member'). The Dessel Member is a very well sorted fine-grained sand with a modal grain size of $170 \pm 20 \mu \mathrm{m}$. The Diest 'member' is a poorly sorted mediumgrained sand with a modal grain size of $257 \pm 55 \mu \mathrm{m}$ (Fig. 6). The Diest Formation has a similar heavy mineral composition to the Berchem Formation, though with a smaller proportion of epidote and amphiboles and a larger proportion of tourmaline and metamorphic minerals. The Dessel Member is more similar to the Berchem Formation than the Diest 'member' though the internal variation is also very large, certainly in the Diest 'member'. In the Dessel Member, epidote and amphiboles represent 14 to $44 \%$ of the heavy mineral assemblage with an average of $27 \%$. The Dessel Member contains 20 to $35 \%$ of garnet with an average of $27 \%$. The percentage of tourmaline and metamorphic minerals is on average $15 \%$, ranging from 11 to $20 \%$. Zircon and rutile range from 24 to $39 \%$, with an average of $30 \%$. In the Diest 'member', the percentage of epidote and amphiboles is lower, ranging from 8 to $39 \%$, with an average of $23 \%$. Garnet represents 8 to $44 \%$ of the heavy mineral assemblage, with an average of $25 \%$.
Tourmaline and the metamorphic minerals are more prominently present in the Diest 'member', ranging from 7 to $39 \%$, averaging $21 \%$. The percentage of zircon and rutile is on average $30 \%$, ranging from 16 to $64 \%$ (Fig. 7).

b) Limburg Campine

The sample of the Diest 'member' measured for grain size is a fine to medium-grained well-sorted clay-rich sand with a modal grain size of $245 \mu \mathrm{m}$ (Fig. 6). Epidote and amphiboles account for 19\% of the heavy mineral composition, based on two samples. The garnet percentage is $9 \%$. Tourmaline and metamorphic minerals make up $17 \%$ of the heavy mineral assemblage. The percentage of zircon and rutile is $55 \%$ (Fig. 7).

c) Hageland

The Dessel Member is only known in the Hageland area from the Veerle core which drills into a deep Diest Formation incision, with Dessel Member sand filling up the lower part. As in the Antwerp Campine, the Dessel Member and Diest 'member' have a different grain size distribution and heavy mineral composition. Based on one sample from the Veerle core, the Dessel Member is a fine-grained well-sorted sand with a mode of $140 \mu \mathrm{m}$. The Diest 'member' is a medium-grained less well sorted sand with a modal grain size of $316 \pm 55 \mu \mathrm{m}$ (Fig. 6). In the Dessel Member, epidote and amphiboles make up $39 \%$ of the heavy mineral composition, based on two samples. The garnet percentage is $14 \%$ and the percentage of tourmaline and metamorphic minerals 


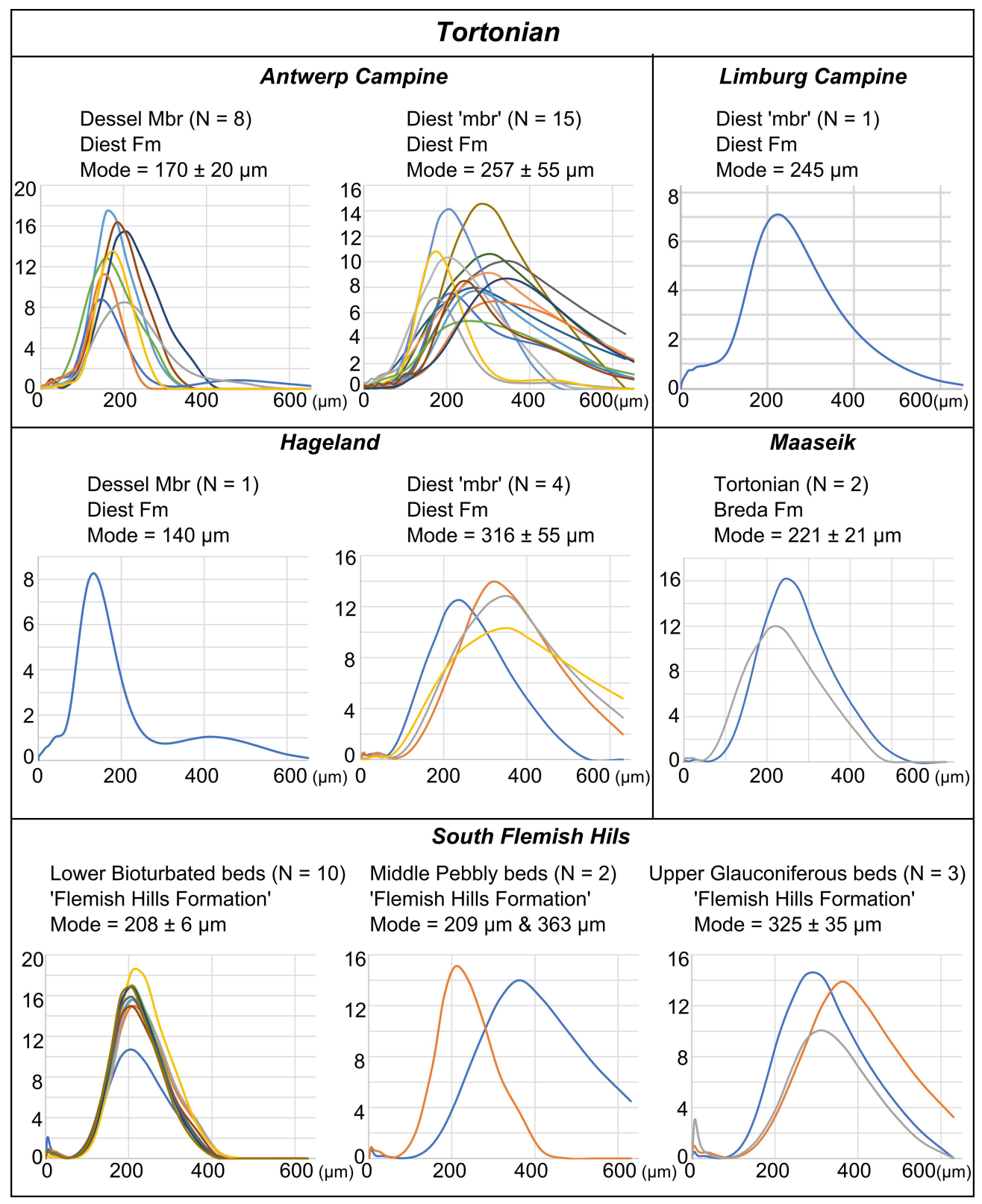

Figure 6. Grain size distribution curves for all samples of the Tortonian, separated per member or formation. The number of samples analyzed per unit $(\mathrm{N})$ and the modal grain size and standard deviation of the modal grain size based on the measured samples are given. Different colors are used to distinguish between different samples on each plot.

is only $8 \%$. Zircon and rutile account for $40 \%$ of the heavy mineral assemblage. Epidote and amphiboles are slightly less prevalent in the Diest 'member', ranging from 11 to $38 \%$, with an average of $28 \%$. Garnet makes up only 1 to $4 \%$ of the heavy mineral composition, with an average of $3 \%$. The percentage of tourmaline and metamorphic minerals is significantly higher compared to the Dessel Member, ranging from 30 to 45\%, with an average of $36 \%$. Andalusite is a significant component in this sand $(5 \%)$, as well as sillimanite $(2 \%)$. Zircon and rutile account for 25 to $42 \%$ of the heavy mineral composition, with an average of $34 \%$ (Fig. 7 ).

d) Southern Ruhr Valley Graben (Maaseik)

Based on two samples, the Tortonian sediments of the Maaseik core, biostratigraphically correlated with the Dessel and Deurne Members, are rather well sorted fine-grained sand with a modal grain size of $221 \pm 21 \mu \mathrm{m}$ (Fig. 6). Epidote and amphiboles constitute $40 \%$ of the heavy mineral composition, ranging from 37 to $44 \%$, based on three samples. Garnet accounts for $15 \%$ of the composition, with a range from 15 to $16 \%$. The percentage of tourmaline and metamorphic minerals ranges from 13 to $22 \%$, with an average of $18 \%$ and the percentage of zircon and rutile has a range of 19 to $32 \%$, averaging $27 \%$ (Fig. 7).

e) Flemish Hills

Grain size data for the Flemish Hills 'formation' gathered by Janssens (2017) are used for this section. The lower bioturbated beds of the Flemish Hills 'formation' have a very consistent grain size distribution. They are well sorted and fine-grained with a modal grain size of $208 \pm 6 \mu \mathrm{m}$. Two samples of the middle pebbly beds were analyzed: one sample is well sorted and fine-grained with a mode of $209 \mu \mathrm{m}$, while the other is medium-grained and poorly sorted with a mode of $363 \mu \mathrm{m}$. The upper glauconiferous beds, which most resemble the Hageland Diest sand due to their elevated glauconite content, are also medium-grained and less well sorted with a modal grain size of $325 \pm 35 \mu \mathrm{m}$ (Fig. 6). The heavy mineral composition of the three subunits is quite similar, dominated by tourmaline and the metamorphic minerals and with a slight increase in epidote towards the top (Fig. 7). Andalusite is a significant component in all subunits. In the lower bioturbated beds, no epidote is present and amphiboles make up 0 to $2 \%$ of the heavy mineral composition. No garnet is present. Tourmaline and the metamorphic minerals account for 47 to $69 \%$ of the heavy mineral composition, with an average of $58 \%$. Andalusite $(9 \%)$ and sillimanite (3\%) are important components. The percentage of zircon and rutile is 29 to $49 \%$, averaging $39 \%$. The middle pebbly beds contain no amphibole, based on one sample. The percentage of epidote and garnet is both $2 \%$. Tourmaline and metamorphic minerals dominate the unit with $73 \%$. Both andalusite $(8 \%)$ and sillimanite $(7 \%)$ are important components. Zircon and rutile account for $21 \%$. In the upper glauconiferous beds, again no amphibole is present and the percentage of epidote is 0 to $10 \%$, with an average of $3 \%$. The percentage of garnet is 1 to $4 \%$ with an average of $2 \%$. Tourmaline and the metamorphic minerals account for 50 to $74 \%$ of the heavy mineral composition, with an average of $63 \%$. Andalusite (4\%) and sillimanite $(2 \%)$ are both 
Figure 7. Pie charts of the heavy mineral composition for all samples of the Tortonian, separated per member or formation. The number of samples analyzed per unit $(\mathrm{N})$ is given. The mineral groups which are related to a northern provenance, according to the results of Verhaegen et al. (2019), are delineated with a blue line. The mineral groups which are related to a southern provenance are delineated with a red line. $\mathrm{Zrn}=$ zircon, Ti-group = titanium-group minerals (mainly rutile), Other $=$ accessory minerals, Tur $=$ tourmaline, $\mathrm{Ky}$ $=$ kyanite, And = andalusite, $\mathrm{Si}$ $=$ sillimanite, $\mathrm{St}=$ staurolite, Grt = garnet, Ep-group = epidote-group minerals (mainly epidote and clinozoisite), $\mathrm{Hbl}=$ hornblende.

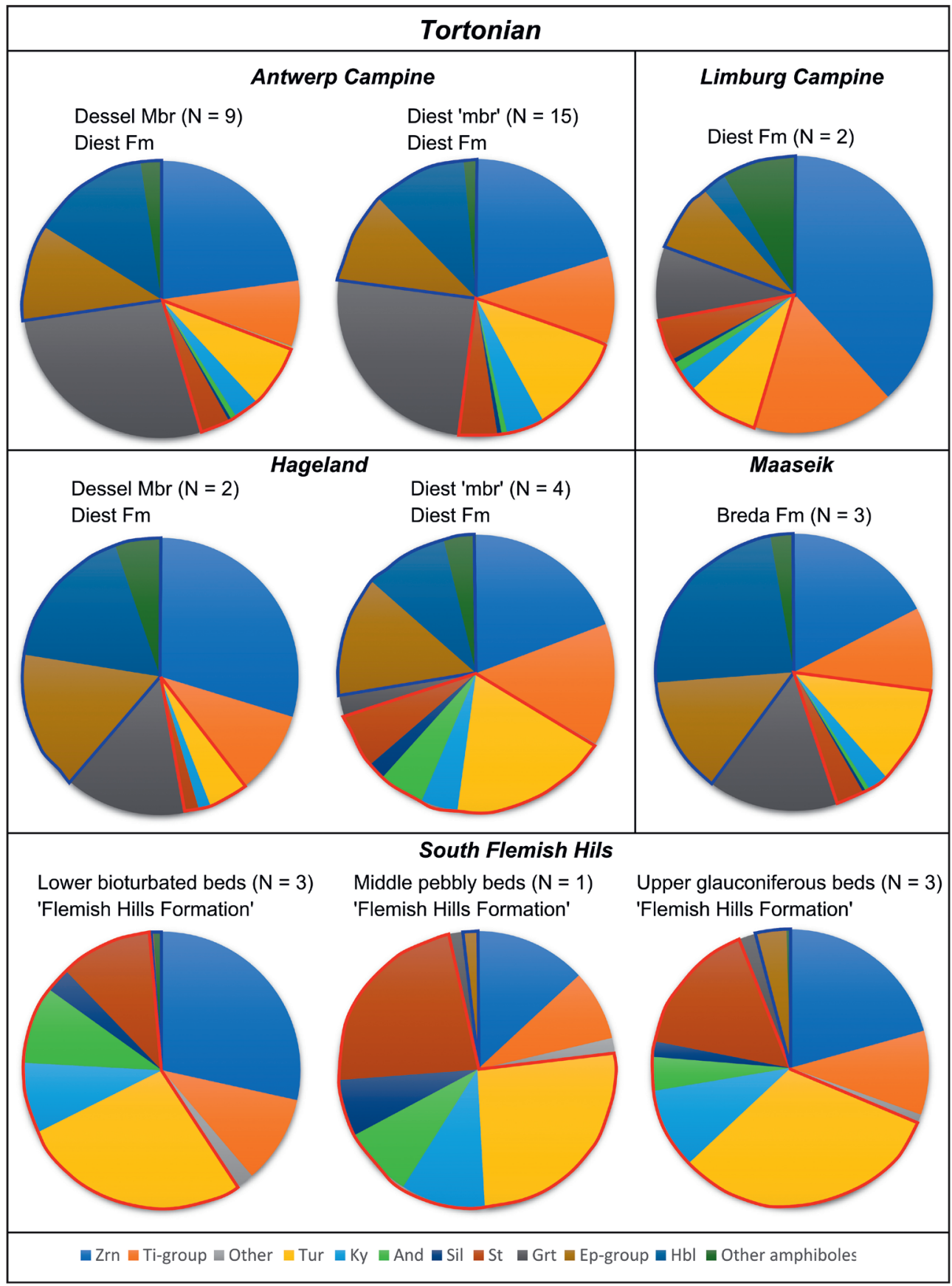

important components. The percentage of zircon and rutile ranges from 25 to $35 \%$ with an average of $30 \%$. It must be noted that the sediments of the Flemish Hills 'formation' are deeply weathered, as signified by the total oxidation of glauconite.

\subsubsection{Messinian - Pliocene}

\section{a) Antwerp Campine}

The Messinian Kasterlee Formation can be split into samples which are well-sorted clay-poor fine-grained sand and samples which are poorly sorted clay-rich fine-grained sand. The more clay-rich sediments belong to the clayey Kasterlee unit, whereas the sandy samples belong to the Kasterlee-sensu-Gulinck unit in the eastern Antwerp Campine or the typical Kasterlee Formation of the type area more to the west. The problem with the definition of the Kasterlee Formation was discussed above in Section 2. The modal grain size of the different units is similar, however, with an average modal grain size of $187 \pm 19 \mu \mathrm{m}$ (Fig. 8). The heavy mineral assemblage of the typical sandy Kasterlee Formation of the western Antwerp Campine and the clayey Kasterlee unit in the eastern Antwerp Campine is rather similar and distinct from the Kasterlee-sensu-Gulinck unit in the eastern Antwerp Campine. In the typical Kasterlee Formation of the type area, based on two samples, the content of epidote and amphiboles is $30 \%$. Garnet represents $15 \%$ of the heavy mineral assemblage. Tourmaline and the metamorphic minerals account for $16 \%$ and zircon and rutile account for $39 \%$ of the heavy mineral composition. In the clayey Kasterlee unit, the epidote and amphibole content ranges from 4 to $35 \%$, with an average of $16 \%$. The garnet percentage ranges from 1 to $27 \%$, with an average of $13 \%$. Tourmaline and the metamorphic minerals represent 16 to $41 \%$ of the heavy mineral assemblage, with an average of $26 \%$. In contrast to most previous units, andalusite is a significant component $(>1 \%)$, with an average of $2 \%$. The percentage of zircon and rutile ranges from 12 to $60 \%$, with an average of $44 \%$. Based on two samples of the Kasterlee-sensu-Gulinck unit of the eastern Antwerp Campine, epidote and amphiboles make up only $6 \%$ of the heavy mineral composition. The garnet percentage is $5 \%$. Tourmaline and the metamorphic minerals represent $58 \%$ of the heavy mineral assemblage. Andalusite is a major component with a percentage of $8 \%$. The percentage of zircon and rutile is $28 \%$ (Fig. 9).

Three of the measured samples of the Pliocene Mol Formation, all from the ON-Dessel-2 core, have a well-sorted fine-grained grain size distribution, similar to the samples of the typical Kasterlee Formation and Kasterlee-sensu-Gulinck unit. The average modal grain size of the samples is $179 \pm 1 \mu \mathrm{m}$. The upper sample measured, which belongs to the coarser upper Mol 

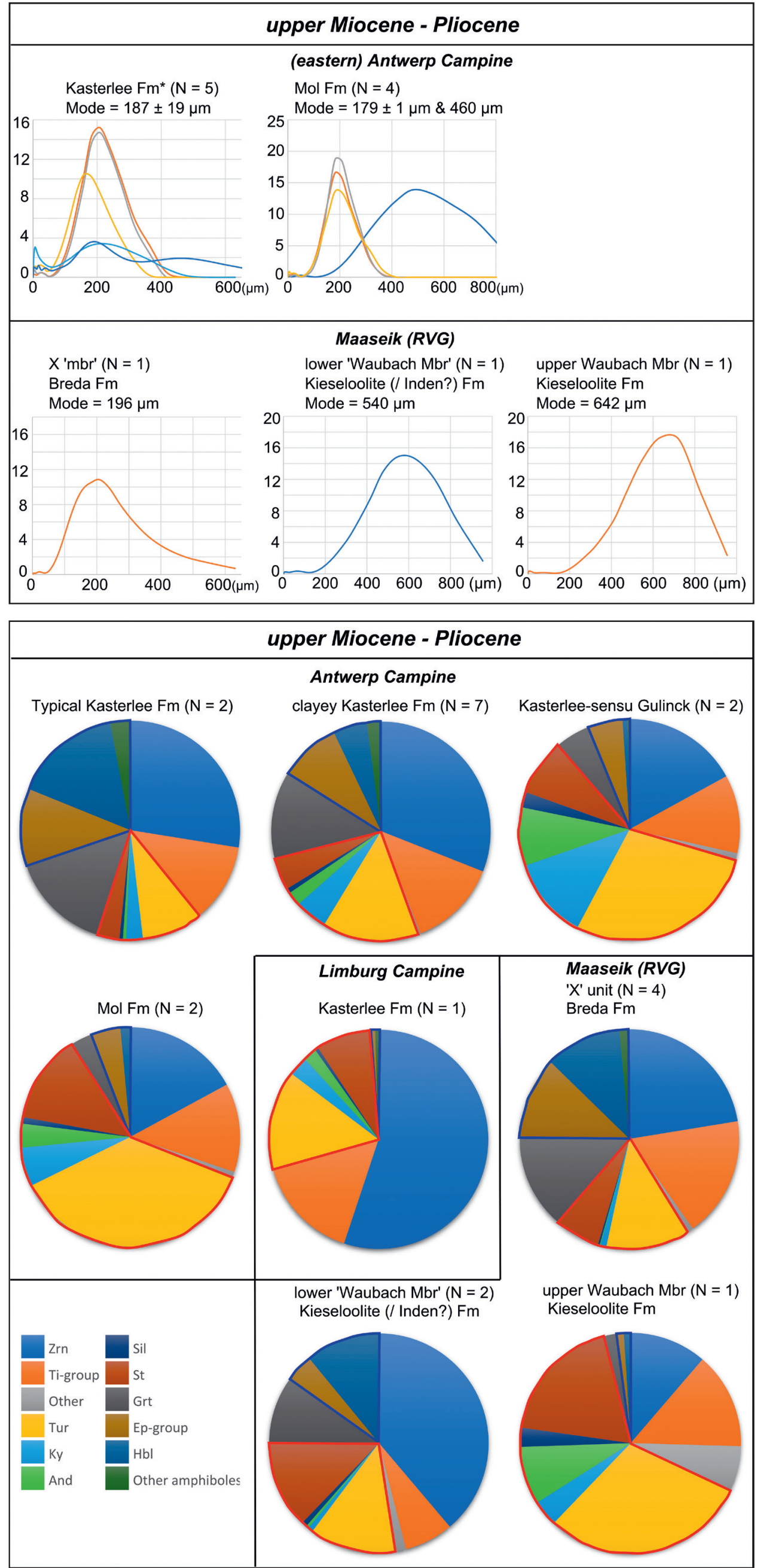

Figure 8. Grain size distribution curves for all samples of the upper Miocene to Pliocene, separated per member or formation. The number of samples analyzed per unit $(\mathrm{N})$ and the modal grain size and standard deviation of the modal grain size based on the measured samples are given. Different colors are used to distinguish between different samples on each plot. * Samples of the Kasterlee Formation include the clayey Kasterlee unit (clay-rich samples, the blue flatter curves) and samples of the typical Kasterlee and Kasterlee-sensuGulinck (the well-sorted fine sand curves).
Figure 9. Pie charts of the heavy mineral composition for all samples of the upper Miocene to Pliocene, separated per member or formation. The number of samples analyzed per unit $(\mathrm{N})$ is given. The mineral groups which are related to a northern provenance, according to the results of Verhaegen et al. (2019), are delineated with a blue line. The mineral groups which are related to a southern provenance are delineated with a red line. $\mathrm{Zrn}$ $=$ zircon, Ti-group $=$ titaniumgroup minerals (mainly rutile), Other $=$ accessory minerals, Tur $=$ tourmaline, $\mathrm{Ky}=$ kyanite, And = andalusite, Sil $=$ sillimanite, $\mathrm{St}=$ staurolite, Grt $=$ garnet, Ep-group $=$ epidote-group minerals (mainly epidote and clinozoisite), $\mathrm{Hbl}=$ hornblende. 
Formation, is a poorly sorted medium to coarse-grained sand with a modal grain size of $460 \mu \mathrm{m}$ (Fig. 8). The heavy mineral assemblage of the coarse-grained sample and the analyzed finergrained sample is very similar and these are also very similar to the Kasterlee-sensu-Gulinck unit of the eastern Antwerp Campine. Epidote and amphibole only represent $6 \%$ of the heavy mineral assemblage in the Mol Formation, based on the two analyzed samples. Garnet is also not well represented, with only $3 \%$. Tourmaline and the metamorphic minerals are the dominant group in the Mol Formation, representing $60 \%$ of the heavy mineral assemblage. Most of this group is made up by tourmaline (37\%). As in the Kasterlee Formation, andalusite is a significant component (4\%). Zircon and rutile make up 30\% of the heavy mineral assemblage (Fig. 9).

b) Limburg Campine

No samples were measured for grain size of the Kasterlee Formation from this area. Based on one sample, epidote and amphiboles represent only $1 \%$ of the heavy mineral assemblage. No garnet is present. The percentage of tourmaline and metamorphic minerals is $28 \%$. The sample is dominated by zircon and rutile $(71 \%)$, mainly due to a large proportion of zircon (55\%) (Fig. 9).

c) Southern Ruhr Valley Graben (Maaseik)

Based on Vandenberghe et al. (2005) the ' $\mathrm{X}$ ' unit at the top of the Breda Formation in the Maaseik core has a Messinian age. Based on new biostratigraphical data analyzed by Louwye \& Vandenberghe (2020, this volume), however, bed ' $\mathrm{X}$ ' can be assigned a late Tortonian age. It is a rather poorly sorted finegrained sand with a modal grain size of $196 \mu \mathrm{m}$, based on one sample (Fig. 8). The heavy mineral composition of the ' $\mathrm{X}$ ' unit includes 20 to $29 \%$ of epidote and amphiboles with an average of $25 \%$ and 7 to $17 \%$ of garnet with an average of $14 \%$. Tourmaline and metamorphic minerals make up 16 to $27 \%$ of the composition, averaging $20 \%$. The average content of zircon and rutile is $40 \%$, ranging from 26 to $49 \%$ (Fig. 9).

The Waubach Member, as defined in Vandenberghe et al. (2005), is now subdivided into two different units in Vandenberghe et al. (2020, this volume). Both the lower and upper unit are poorly sorted coarse-grained sands. The lower unit has a modal grain size of $540 \mu \mathrm{m}$ while the upper unit is even coarser with a modal grain size of $642 \mu \mathrm{m}$ (Fig. 8). Based on two samples, the lower unit contains $15 \%$ of epidote and amphiboles and $10 \%$ of garnet. Tourmaline and the metamorphic minerals make up $27 \%$ of the heavy mineral composition and zircon and rutile account for $46 \%$. In the upper unit, based on one sample, epidote and amphiboles make up $2 \%$ of the composition and garnet also accounts for $2 \%$. The percentage of tourmaline and metamorphic minerals is $64 \%$ and the percentage of zircon and rutile is $25 \%$. Andalusite $(9 \%)$ and sillimanite $(3 \%)$ are important components. The upper unit is the only unit defined in this study in which the category of other minerals, which do not belong to any of the defined categories, makes up a significant amount $(7 \%)$ of the heavy mineral composition (Fig. 9). These include pumpellyite, allanite and spinel.

\subsection{Log-ratio analysis}

The two main principal components of the PCA of the clrtransformed heavy mineral data account for $58 \%$ of the variation. The resulting variables factor map is very similar to the PCA of the literature data discussed in Verhaegen et al. (2019) (Fig. 10). A noticeable difference is the positive correlation of garnet with epidote and amphibole along PC1. These three mineral groups are negatively correlated with the aluminosilicate polymorphs, staurolite, tourmaline and accessory minerals. Zircon and rutile are approximately orthogonal to the previously mentioned minerals along PC2.

In Verhaegen et al. (2019), log-ratio plots of LR1 ( $\log (($ epidote + inosilicate) $) /($ tourmaline + aluminosilicate polymorphs+staurolite))) versus LR2 (Log (zircon+rutile+accessory minerals)/garnet)) were constructed based on the component relationships from the PCA. In general, for the studied Neogene sediments, there is a decrease in LR1 from the northwest to the southeast of the study area and from the lower Miocene to Pliocene. LR2 is higher in more weathered sediments and is generally higher in the southwest of the study area and in younger sediments. Mainly in the eastern Antwerp Campine area, there is a clear change in heavy mineral composition from lower Miocene to Pliocene based on these plots, while heavy mineral composition remains rather constant throughout the Neogene in the western Antwerp Campine area (Fig. 11). As the new heavy mineral data in the current study are from the same region and time-period as the literature data of Verhaegen et al. (2019) and indeed show a quite similar relationship of variables on the PCA plot, these data are added on the plots of the Antwerp Campine based on the literature data (Fig. 11). The new data plot in or near to the $2 \sigma$-confidence ellipses based on the literature data, confirming little change throughout the Neogene in the western Antwerp Campine area and a decreasing LR1 and increasing LR2 throughout the Neogene in the eastern Antwerp Campine area. The LR1 values of the Berchem Formation samples of the western Antwerp Campine area from the current study are on average higher compared to the literature data, yet the relations between the different units remain similar. For the Kasterlee Formation, the LR1 value is the highest for the typical Kasterlee Formation of the western Antwerp Campine, lower for the clayey Kasterlee unit of the eastern Antwerp Campine area and the lowest for the Kasterlee-sensu-Gulinck unit of the eastern Antwerp Campine area with values similar to the Mol Formation. The Pliocene Poederlee Formation of the western Antwerp Campine has a significantly higher LR1 value than the Pliocene Mol Formation of the eastern Antwerp Campine.

As it may be very useful to extract one single proxy for the heavy mineral composition from the data, another log-ratio (LR3) is constructed, which is a log-ratio of garnet, epidote and amphibole versus tourmaline, zircon, rutile, staurolite, aluminosilicates and accessory minerals. In the new dataset, garnet correlates strongly with epidote and amphibole based on the PCA (Fig. 10b). Zircon and rutile are grouped with tourmaline and the metamorphic minerals since zircon and rutile are classically included in the
Figure 10. Variables factor map of the clr-transformed heavy mineral data of (a) the literature data of Verhaegen et al. (2019) and (b) new data from the current research. Zrn = zircon, $\mathrm{Ti}=$ Ti-group minerals (mainly rutile), Tur = tourmaline, $\mathrm{St}=$ staurolite, Als = aluminosilicate polymorphs, Ky = kyanite, And $=$ andalusite, Sil = sillimanite, Grt = garnet, $\mathrm{Ep}=$ epidote-group minerals, Amp = amphiboles, Other $=$ accessory minerals, $\mathrm{R}$ $=$ zircon, rutile and accessory minerals.

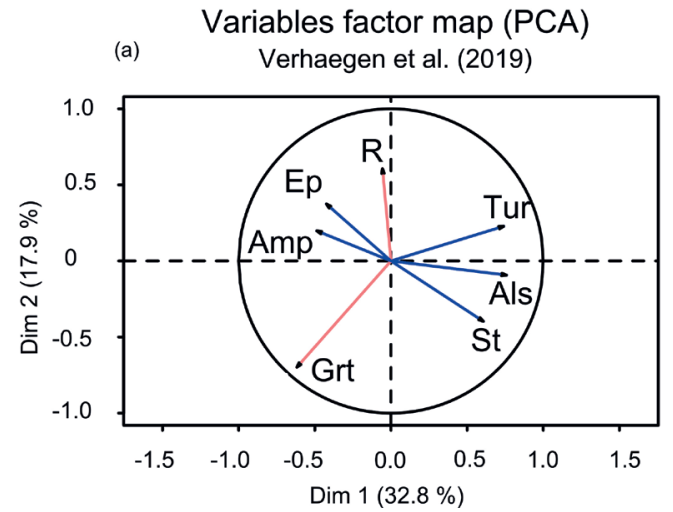

Variables factor map (PCA) erhaegen et al. (2019)

(b)

Variables factor map (PCA) Current research

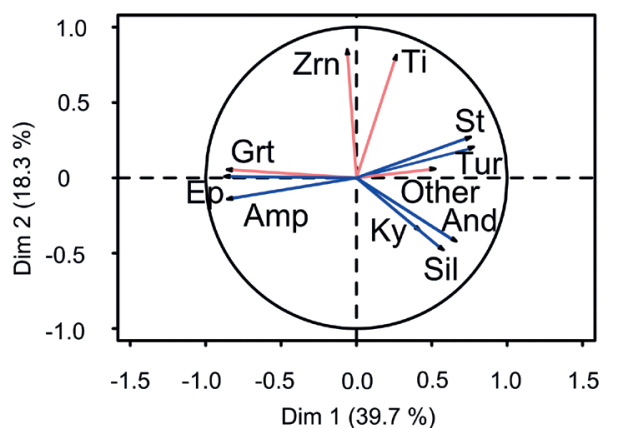



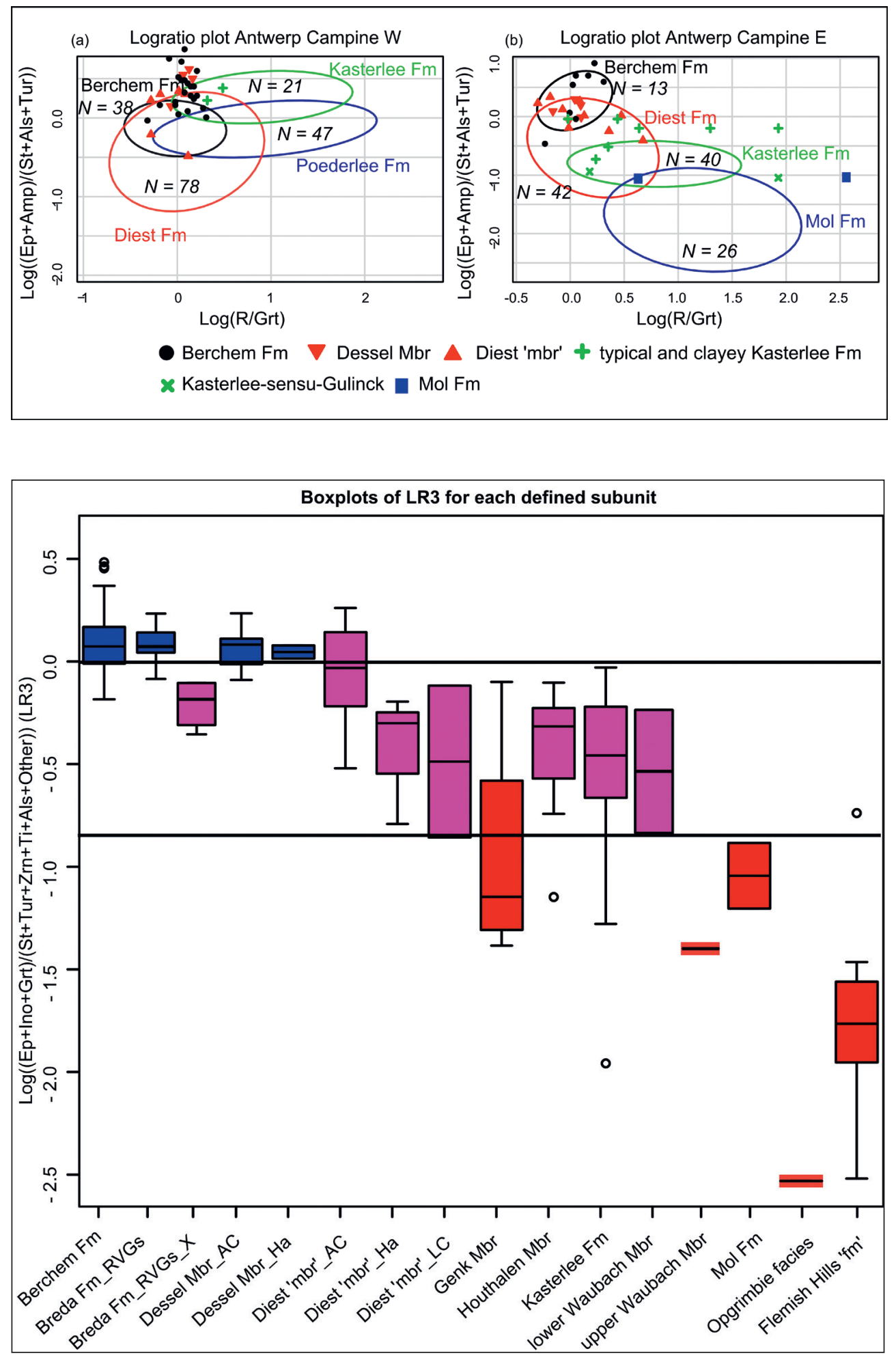

Figure 11. Log-ratio plots of the heavy mineral composition of the Neogene sediments of the (a) western Antwerp Campine and (b) eastern Antwerp Campine. Data ellipses for different units are $2 \sigma$ confidence regions based on literature data from Verhaegen et al. (2019). For each confidence ellipse, the number of samples (N) included in the analysis is given. Individual data points are new data collected for the current research. $\mathrm{R}=$ zircon, Ti-group minerals (mainly rutile) and accessory minerals, Tur $=$ tourmaline, $\mathrm{St}=$ staurolite, $\mathrm{Als}$ $=$ aluminosilicate polymorphs (kyanite, andalusite, sillimanite), Grt $=$ garnet, $\mathrm{Ep}=$ epidote-group minerals, $\mathrm{Amp}=$ amphiboles .
Figure 12. Boxplots of LR3 for each defined subgroup (divided by region and formation/ member). Colors are added to distinguish between units with high LR3 (blue), medium LR3 (purple) and low LR3 (red). "..." RVGs: samples from Maaseik. “..."AC: samples from the Antwerp Campine. "..." Ha: samples from the Hageland hills. “..."LC: samples from the Limburg Campine. $\mathrm{Zrn}=$ zircon, $\mathrm{Ti}=$ Ti-group minerals (mainly rutile), Tur $=$ tourmaline, $\mathrm{St}=$ staurolite, Als = aluminosilicate polymorphs (kyanite, andalusite, sillimanite), Grt = garnet, $\mathrm{Ep}=$ epidote-group minerals, Ino $=$ inosilicaties, Other $=$ accessory minerals. southern mineral assemblage (Edelman \& Doeglas, 1933). LR3 is the highest in the Berchem Formation, the Breda Formation in the Maaseik core and the Dessel Member both in the Antwerp Campine and Hageland area. Not only is the average value of LR3 high in these units, but also the range of values is small (Fig. 12). Units for which the median LR3 value is lower than the first percentile of the LR3 value of Berchem Formation are characterized as having medium-low values. The Antwerp Campine Diest 'member' ranges from high values similar to the Berchem Formation to lower values. Units with only medium-low values are the Limburg Campine Diest 'member', Hageland Diest 'member', Houthalen Member and Kasterlee Formation. In the Kasterlee Formation the range spreads to very low values due to the strongly increased proportion of tourmaline and metamorphic minerals in the Kasterlee-sensu-Gulinck unit, which is similar to the Mol Formation. The ' $\mathrm{X}$ ' bed on top of the Breda Formation in the Maaseik core as well as the lower Waubach Member also have medium-low values for LR3. For units which have low to very low LR3 values, the median value is lower than the first percentile of the Limburg Campine Diest Formation. Low LR3 values are present for the upper Waubach Member, Mol Formation and Genk Member, though the range of values is very large for the Genk Member. The lowest LR3 values are recorded for the Opgrimbie facies and Flemish Hills 'formation'.

\subsection{Detail of the Dessel cores}

The Dessel cores (ON-Dessel-2 and ON-Dessel-5) are situated in the eastern Antwerp Campine region, at the center of mixing between northern and southern sediment input (Verhaegen et al., 2019), and provide a complete section from the lower Miocene 
Figure 13. Variation in heavy mineral composition and grain size for the Dessel cores (ONDessel-5 and ON-Dessel-2). D $=$ Depth. HM $=$ Heavy mineral composition. $\mathrm{LR} 3=\log ($ (epid ote+inosilicate+garnet)/ (tourm aline+aluminosilicate + stauroli te+zircon+rutile+other)). GS = Grain size. * the LR3 value at the top of the Diest Formation is based on the average of samples of the Diest Formation from the nearby Mol core (at $39 \mathrm{~m}$ depth) and Retie core (at $34 \mathrm{~m}$ depth), due to the lack of data in the ON-Dessel-2 core. Zrn $=$ zircon, Ti-group $=$ titaniumgroup minerals (mainly rutile) Other $=$ accessory minerals, Tur $=$ tourmaline, $\mathrm{Ky}=$ kyanite, And $=$ andalusite, Sil = sillimanite, St $=$ staurolite, Grt = garnet, Ep-group = epidote-group minerals (mainly epidote and clinozoisite), $\mathrm{Hbl}=$ hornblende, Amp $=$ other amphiboles.

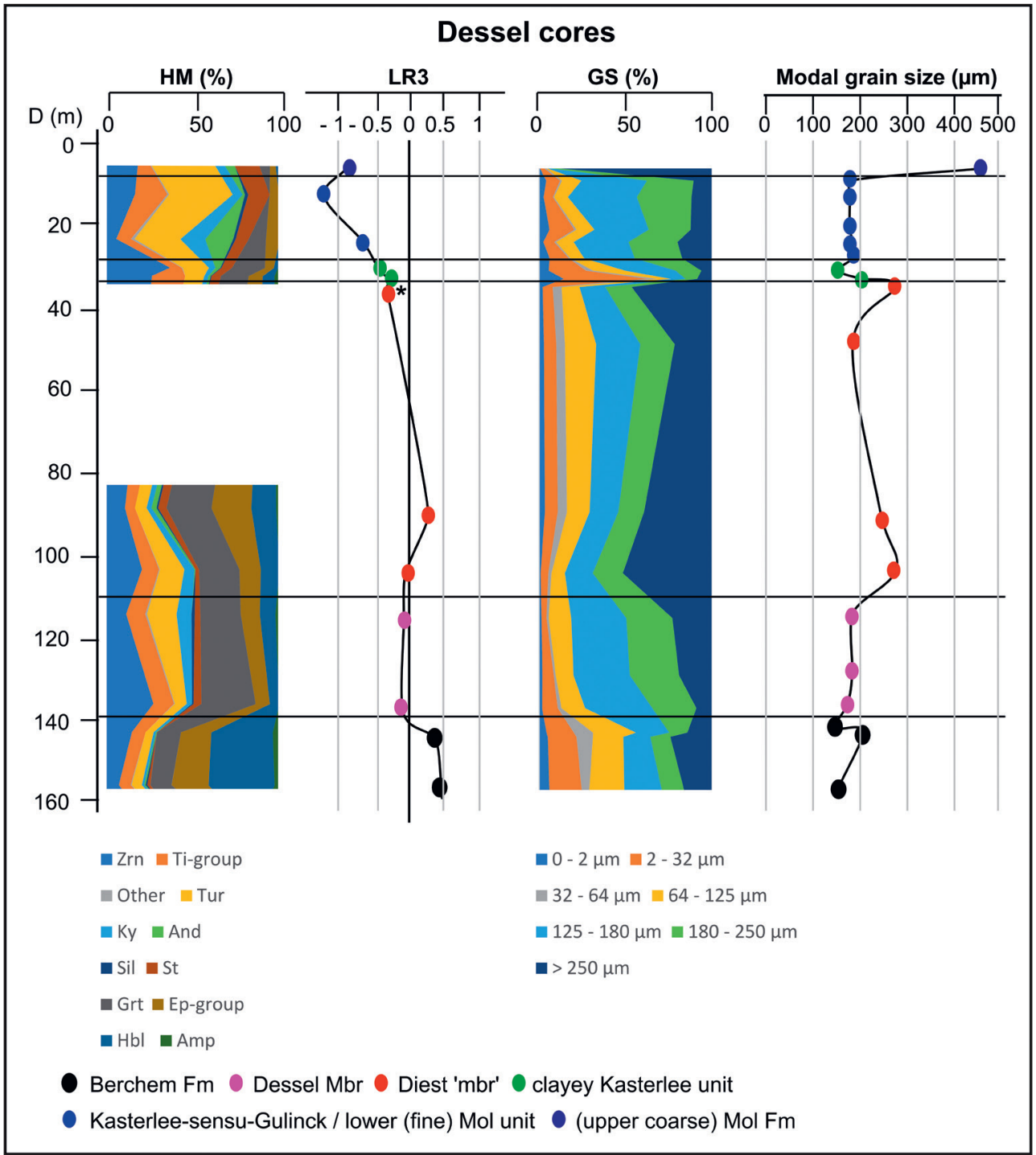

Berchem Formation up to the Pliocene Mol Formation. As such they can be used as a test case for the variation in heavy mineral composition and grain size distribution across the Neogene. The cores are described using heavy mineral composition, the heavy mineral provenance proxy LR3 (Log( (epidote+inosilicate+ garnet)/ (tourmaline+aluminosilicate+staurolite+zircon+rutile + other))), grain size distribution as composition and modal grain size (Fig. 13). LR3 does not appear to be primarily related to modal grain size, as there are strong variations in LR3 in samples with differing modal grain size and similar values of LR3 in samples with strongly differing modal grain size, such as is the case for the Mol Formation. The Berchem Formation is characterized by a high LR3 value, caused mainly by a significant amount of hornblende and to a lesser extent epidote and garnet. The samples from this formation have a large silt and very fine sand fraction $(2-125 \mu \mathrm{m})$ and a modal grain size of 145 to $210 \mu \mathrm{m}$. The overlying Dessel Member of the Diest Formation is a well-sorted fine-grained sand with a large fine sand fraction $(125-250 \mu \mathrm{m})$ and less clay and silt compared to the Berchem Formation. The modal grain size is 170 to $190 \mu \mathrm{m}$. The LR3 value of the Dessel Member is lower compared to the Berchem Formation, mainly due to an increased zircon content. Tourmaline, kyanite and staurolite are also slightly increased. Garnet is more important relative to epidote and hornblende. The Dessel Member can be distinguished from the Berchem Formation based on the relative increase in zircon and garnet, related to a strong decrease in hornblende. Also, there is a decrease in clay and silt fraction and an increase in medium sand fractions. The shift in heavy mineral composition is not likely a result of sorting as zircon is a typical fine-grained mineral while garnet is a typical coarse-grained mineral and both minerals increase. The Dessel Member is overlain by the Diest 'member' of the Diest Formation which has a modal grain size between 200 and $300 \mu \mathrm{m}$ and a larger fraction of medium sand $(>250 \mu \mathrm{m})$. In the lower part of the Diest 'member' the LR3 value is still high mainly because of a high amount of garnet and epidote. At the top of the Diest Formation the modal grain size is variable going from $200 \mu \mathrm{m}$ to almost $300 \mu \mathrm{m}$ at the boundary with the Kasterlee Formation. As no useable data of the heavy mineral composition of the top of the Diest Formation are available from the Dessel cores an average LR3 value from the nearby Mol and Retie cores at approximately the same stratigraphic position is given. The LR3 value is lower compared to the Dessel Member and the base of the Diest 'member'. The clayey Kasterlee unit has a modal grain size lower than $200 \mu \mathrm{m}$ and a very large clay and silt fraction. The LR3 value of the clayey Kasterlee unit is lower than in the underlying units, similar to the top of the Diest Formation, mainly due to an increase in zircon and rutile and a decrease in garnet and epidote. This may be partly due to a sorting effect yet there is also a slight increase in metamorphic minerals (staurolite and $\mathrm{Al}_{2} \mathrm{SiO}_{5}$ polymorphs) and a similar value is achieved in the coarser top of the Diest Formation. In the Kasterlee-sensu-Gulinck unit or lower Mol unit the LR3 value strongly decreases $(<-0.5$ down to $<-1$ ) due to a significant increase in tourmaline and metamorphic minerals. The grain size of the Kasterlee-sensu-Gulinck unit is dominated by fine sand $(125-180 \mu \mathrm{m})$ and a modal grain size below $200 \mu \mathrm{m}$. The (upper) Mol Formation is much coarser than the lower Mol unit, dominated by medium to coarse sand $(>250 \mu \mathrm{m})$, with a modal grain size of almost $500 \mu \mathrm{m}$. The LR3 value is still very low, similar to lower Mol unit or Kasterleesensu-Gulinck unit. 


\section{Discussion}

\subsection{Provenance interpretations}

The general inferred provenance trends based on variations in heavy mineral assemblage which were uncovered using literature data in Verhaegen et al. (2019) can be confirmed based on the analysis of the new heavy mineral dataset. Overall there is an increase in the amount of aluminosilicate polymorphs, staurolite and tourmaline relative to epidote and inosilicates from the lower Miocene to the Pliocene and from the north to the south. In contrast to the literature dataset, garnet also correlates strongly with epidote and inosilicates, indicating that garnet is also related to a northern marine sediment provenance, as inferred by Edelman $\&$ Doeglas (1933). This difference can be explained by the lower number of outcrop and shallow subcrop samples in comparison with the literature dataset and perhaps also by a difference in counting technique between the literature data (point counting) and the data collected in the current study (ribbon counting). Because of this, the chemical weathering effect on garnet (Gullentops, 1963; Verhaegen et al., 2019) is less pronounced and its provenance significance as a northern marine mineral is better preserved. It must be noted that the LR3 log-ratio is the statistical equivalent of the classic A-B provenance model by Edelman \& Doeglas (1933).

In the Antwerp Campine area, the relative increase in the southern minerals is apparent from the upper Tortonian Diest 'member' onwards. The lower Tortonian Dessel Member is still very similar to the underlying Berchem Formation. In the Hageland area as well, there is no clear southern signature in the Dessel Member, whereas in the Diest 'member' the southern signature is well pronounced. In the Limburg Campine area, the southern signature is already visible in the lower Miocene. In the upper middle Miocene Opgrimbie facies, there are no northern minerals present. This may be caused exclusively by chemical weathering due to leaching below lignite beds. However, as the content of ultrastable minerals zircon and rutile is also relatively low compared to the southern minerals, it is likely to be a combination of weathering and provenance. Based on a more detailed analysis of the Opgrimbie facies, Gullentops (1973) suggests both intense chemical weathering in the source area as well as acidic leaching related to the lignite. Differences between zircon and rutile versus tourmaline and metamorphic mineral content could be caused by sorting effects. In the RVG, the southern signature only strongly increases from the upper Tortonian to Messinian onwards. This jump coincides with the transition from marine Breda Formation to fluvial Kieseloolite Formation, at the ' $\mathrm{X}$ ' bed. The Flemish Hills 'formation' has a strong southern signature which is more pronounced than in any other unit, except for the Opgrimbie facies. The Flemish Hills 'formation' is the only unit with a significant initial glauconite content, now oxidized, which is characteristic for marine units, yet has a strong southern heavy mineral signature. All other units with a southern signature are continental quartz-dominated units. This may be linked to the strongly weathered nature of the Flemish Hills 'formation' which likely strongly altered its initial heavy mineral signature.

It is apparent that andalusite is only a significant component within the aluminosilicate polymorph group in southern units and upper Miocene to Pliocene units, which are the Hageland Diest 'member', the Flemish Hills 'formation', the middle Miocene Opgrimbie facies in the southeast, the Messinian Kasterlee Formation, the Pliocene Mol Formation and the upper Miocene to Pliocene units in the Ruhr Valley Graben. A high andalusite content has been recognized in Belgian Eocene sediments and in Paleogene sediments of the Paris Basin (Gullentops, 1963; Geets et al., 1985; Larue \& Etienne, 2000), being ultimately sourced from the Massif Central, Vosges and/or Bretagne. A high andalusite content could thus indicate reworking of these sediments from the south into the Campine Basin in the Neogene.

The increase in southern minerals is mainly apparent above the Mid Miocene Unconformity (MMU), from the Tortonian onwards. The main increase in southern sediment input above the MMU coincides with the strong northward expansion of the Rhine delta and the increased clastic sediment load (Schäfer et al., 2005; Schäfer \& Utescher, 2014; Vandenberghe et al., 2014).
The provenance interpretations are based on the assumption that the variations in heavy mineral composition can be interpreted mainly in terms of provenance changes. However, sediment compositional differences are often linked to grain size differences due to hydraulic sorting processes. Based on a visual inspection of the grain size distributions of all different units, it is clear that there is significant variation in grain size between all different units. In general, sediments with a southern provenance signature are coarser-grained than sediments with a northern provenance signature. The general difference in grain size can also be explained by provenance instead of sorting, as the southern sediments delivered by the Rhine-Meuse fluvial system are expected to be coarser than the northern marine sediments. Some units have a large intraformational variation in grain size, such as the Antwerp Campine Tortonian Diest 'member' which also has a large compositional variation, indicating significant mixing. In the Diest Formation, there is a clear distinction between the fine-grained Dessel Member, which has a northern provenance signature, and the coarser-grained Diest 'member', which has a more mixed provenance signature. The relation between finegrained sediment and a northern provenance signature, compared to more coarse grained sediments and a southern provenance signature does not seem to be valid for all units, though. Certain units with a southern provenance signature, such as the Kasterlee Formation and lower Mol unit also have a fine grain size which would not be expected if the composition would be purely the result of sorting.

\subsection{Stratigraphic implications}

\subsubsection{Berchem - Bolderberg Formation}

The Berchem Formation and Bolderberg Formation are laterally occurring units deposited during the lower to middle Miocene in the Antwerp Campine and Limburg Campine, respectively, with similar glauconite-rich sand lithology. These units are separated by the deep incision of the Diest Formation in the Hageland gully system. As they are lateral time and lithology equivalent units, it would be an option to group them into one formation. Based on the heavy mineral composition, however, there is a significant difference between both formations, confirmed by the literature data collected in Verhaegen et al. (2019). Both the marine Houthalen Member and the continental Genk Member have a higher proportion of southern heavy minerals compared to the marine Berchem Formation, which has a strong northern heavy mineral signature. The Houthalen Member likely correlates with one or more members of the Berchem Formation, yet based on the heavy mineral composition it is not possible to determine how these units actually correlate. Since the architecture of the original continuous unit over the now-eroded transitional zone cannot be exactly determined, it is suggested to leave them as two separate units with differing characteristics (see also Louwye et al., 2020, this volume).

\subsubsection{Diest Formation}

There are significant differences between different units of the Tortonian Diest Formation, both regionally and stratigraphically. Different models have been proposed to explain the deposition of the Diest Formation (Gullentops, 1957; Vandenberghe et al., 2014; Houthuys, 2014; Houthuys \& Mathijs, 2018). The distinction between the Deurne and Dessel Members, the Antwerp Campine Diest 'member', the Hageland Diest 'member' and the Limburg Campine Diest 'member' is an essential element in all these models. The Dessel Member can be clearly distinguished from the Diest 'member' based on the samples analyzed for this study. The Dessel Member has a modal grain size of $170 \pm 20 \mu \mathrm{m}$ in the Antwerp Campine Basin and $140 \mu \mathrm{m}$ in the Hageland area (based on only one sample), compared to a significantly coarser modal grain size for the Diest 'member' of $257 \pm 55 \mu \mathrm{m}$ in the Antwerp Campine Basin and $316 \pm 55 \mu \mathrm{m}$ in the Hageland area, and one sample of the Limburg Campine area shows a modal grain size of $245 \mu \mathrm{m}$. This finer grain size of the Dessel Member is also coupled with a more northern provenance signature, which can be observed by a slightly higher LR3 value (more garnet, epidote and amphibole) for the Dessel Member compared to the Antwerp Campine Diest 'member'. The LR3 value is very similar for the Antwerp Campine 
and Hageland Dessel Member and it is significantly lower in the Hageland and Limburg Campine Diest 'member' (Fig. 12). The andalusite content, which may be a good indicator of a southern provenance is similar in the Dessel Member and the Antwerp Campine Diest 'member' but higher in the Limburg Campine Diest 'member' and the highest in the Hageland Diest 'member'. The data appear to fit the model proposed by Vandenberghe et al. (2014) in which the Dessel Member is an individual sequence deposited prior to the Diest 'member' as a shallow and low energy transgression from the north.

Based on the data discussed above there is also a distinction between the regional Diest 'member' units, whereby the Hageland Diest Formation has a more southern provenance signature compared to the Antwerp Campine Diest Formation, with the Limburg Campine Diest Formation in between. This result was also obtained from the analysis of heavy mineral literature data in Verhaegen et al. (2019) (Fig. 14). The differences between the Hageland Diest 'member' and the Antwerp Campine Diest 'member' support the hypothesis that they were deposited in different sequences, with the Hageland Diest 'member' being influenced more by southern input and reworking of sediments with a southern source signature. The uplift of the Brabant Massif and the Hageland Hills after deposition of the Hageland Diest sand may have partly shielded the Antwerp Campine Diest sand from this southern influence (Vandenberghe et al., 2014). In the model of Houthuys (2014) the deposition of the Dessel Member and the Hageland Diest 'member' is assumed to be coeval, which is unlikely based on the data collected in this study.

An important element of the classical model of Gullentops (1957) is the connection of the southern Campine Basin with the English Channel through a sea strait. This hypothesis was substantiated by the recognition of the Diest Formation on top of the Flemish Hills. The stratigraphic position of the sediments on top of the Flemish Hills, however, is very uncertain. According to Houthuys (2014), the depositional environments of the Hageland Diest 'member' and the Flemish Hills 'formation' are incompatible, based on an analysis of the sedimentological characteristics. Based on the data gathered in this study, the modal grain size of the lower unit of the Flemish Hills 'formation' (208 $\pm 6 \mu \mathrm{m})$, as defined by Houthuys (2014), is significantly finer than that of the Hageland Diest 'member'. The upper unit, however, has a similar modal grain size $(325 \pm 35 \mu \mathrm{m})$ as the Hageland Diest 'member' and also has a higher glauconite content, similar to the Diest Formation. The heavy mineral composition of the Flemish Hills 'formation' is characterized by

\section{Logratio plot Diest Formation}

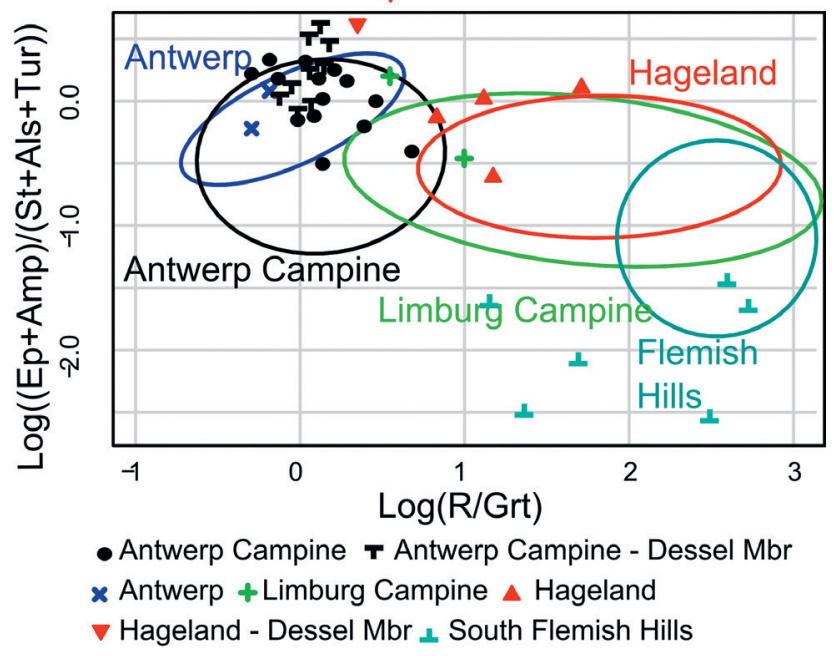

Figure 14. Log-ratio plots of the heavy mineral composition of the Diest Formation across the different defined regions and of the Flemish Hills sand. Data ellipses for different units are $2 \sigma$ confidence regions based on literature data from Verhaegen et al. (2019). Individual data points are new data collected for the current research. $\mathrm{R}=$ zircon, Ti-group minerals (mainly rutile) and accessory minerals, Tur $=$ tourmaline, $\mathrm{St}=$ staurolite, Als $=$ aluminosilicate polymorphs (kyanite, andalusite, sillimanite), Grt = garnet, $\mathrm{Ep}=$ epidote-group minerals, Amp = amphiboles. a very low LR3 value, indicating a strong southern signature. It must be noted, however, that the original heavy mineral signature of the Flemish Hills 'formation' may be significantly altered due to intense chemical weathering, based on the complete oxidation of glauconite, with the capacity of eventually removing unstable components such as amphibole or garnet, if ever present. If chemical weathering is removed it is possible that the original heavy mineral signature of the Flemish Hills 'formation' was similar to that of the Hageland Diest 'member', which is also characterized by a relatively low LR3 value. Both the Flemish Hills 'formation' and the Hageland Diest Formation have a significant proportion of andalusite and sillimanite which are rare in most other units except for the Kieseloolite Formation, Opgrimbie facies, Kasterlee Formation and Mol Formation, which are all units for which an increased southern provenance is assumed. If the Flemish Hills 'formation' and the Hageland Diest 'member' were indeed deposited during the same time, the more intensely weathered nature of the Flemish Hills 'formation' could indicate that those sediments were exposed to subaerial weathering at an earlier stage than the Hageland Diest 'member'. Based on the data available, the Hageland Diest 'member' is the unit most similar to the Flemish Hills 'formation', though it is impossible to confirm a correlation between both as there are also some differences. Possibly, only the upper unit of the Flemish Hills 'formation' correlates with the Hageland Diest 'member', as this unit is most similar to the Diest Sand. In that scenario, the lower units would have been deposited in an earlier stage when a connection between the Atlantic Ocean and Paris Basin and the Hageland gully was not yet fully established. It must be stressed that none of the available models can be conclusively confirmed or denied based on the data presented in this study.

\subsubsection{Kasterlee - Mol Formation}

The Messinian Kasterlee Formation has been defined slightly differently by different authors throughout the years due to its transitional character between the underlying Tortonian Diest Formation and the overlying Pliocene Mol Formation. According to the current stratigraphic consensus, the Kasterlee Formation in the eastern Antwerp Campine area, the area of the Dessel cores, consists of a lower clayey unit and an upper sandy unit. In the past, the clayey unit has also occasionally been incorporated into the top of the Diest Formation. New insights based on log correlations, biostratigraphy and clay mineralogy indicate that the Kasterlee Formation may be limited to the lower clayey unit in this area, while the upper sandy unit, the Kasterlee-sensuGulinck unit, may be either a lower part of the Mol Formation, with reworked elements from the Kasterlee Formation, or a time-equivalent unit of the Kasterlee Formation of the type area with lithological transitional characteristics to the overlying Mol Formation (Vandenberghe et al., 2020, this volume). Based on the data collected in this study, the Kasterlee-sensu-Gulinck unit of the eastern Antwerp Campine area indeed resembles much more the overlying Mol Formation than the underlying Kasterlee and Diest Formations, which makes it feasible to include this upper sandy unit into the Mol Formation. The grain size distribution of the Kasterlee-sensu-Gulinck unit strongly resembles the finegrained lower unit of the Mol Formation in the Dessel core. The heavy mineral composition of the clayey Kasterlee unit is slightly more enriched in southern minerals compared to the Diest Formation, resulting in a lower LR3 value. In the Kasterlee-sensuGulinck unit however, the southern minerals truly dominate the heavy mineral composition, resulting in a very low LR3 value, very similar to that of the overlying Mol Formation. Andalusite is also much more prominent in the Kasterlee-sensu-Gulinck unit.

The proposed new boundary between the clayey Kasterlee Formation and the sandy Mol Formation, including the Kasterleesensu-Gulinck unit at its base, is illustrated for the Dessel core in Figure 13. This new interpretation can also be validated using the Belchim core of Mol analyzed by Gulinck et al. (1963) (Fig. 15). According to their classical interpretation, the clayey Kasterlee unit is the top part of the Diest Formation. The Kasterlee Formation as defined by Gulinck et al. (1963) coincides with the Kasterleesensu-Gulinck unit, overlain by the coarser Mol Formation. In the new interpretation, the clayey Kasterlee unit is the Kasterlee Formation. The fine sandy unit on top is not the Kasterlee 
Formation but the lower Mol unit, which is then followed by a coarser (upper) Mol Formation. This new interpretation is also more logical when looking at the heavy minerals. Using the new definitions, a first slight increase in tourmaline and metamorphic minerals, leading to a decrease in LR3, occurs in the clayey Kasterlee unit, despite the strong decrease in grain size. No strong break in heavy mineral composition is expected between the Tortonian Diest Formation and the Messinian Kasterlee Formation as the Kasterlee Formation is a new sequence within the same sedimentary system. The most important break in heavy mineral composition occurs at the boundary between the clayey Kasterlee unit and the new lower Mol unit (Kasterlee-sensuGulinck). Above this boundary, there is a strong increase in tourmaline and metamorphic minerals, which remains throughout the coarser Mol Formation as well and indicates a strong increase in sediment input from the south. The decrease in the ultrastable minerals zircon and rutile in the coarse upper Mol Formation unit could be explained by the much coarser grain size of that unit, as these ultrastable minerals typically occur in the finer size fractions, which make up only a small fraction of the upper Mol Formation unit.

\subsubsection{Correlation between the Campine Basin and Ruhr Valley} Graben

A correlation between the Diest, Kasterlee and Mol Formations in the Postel-Lommel area in the east of the Campine Basin with the Breda and Kieseloolite Formations in the Maaseik borehole in the Ruhr Valley Graben (RVG) was attempted in Vandenberghe et al. (2005) based on geophysical log signatures and biostratigraphical data. After the more detailed unravelling of the Diest-KasterleeMol units in the Kasterlee-Mol-Postel area this log correlation version was updated (Vandenberghe et al., 2020, this volume fig.6): the high GR (gamma-ray) signature of bed ' $\mathrm{X}$ ' in the Maaseik borehole apparently should correlate with the high GR signature of the clayey Kasterlee unit while the overlying Waubach Member of the Kieseloolite Formation can be split up in a lower part correlating with the lower-Mol or Kasterlee-sensu-Gulinck unit and an upper part correlating with the Mol Formation pro parte. The glauconite-rich sand of the Breda Formation below the ' $X$ ' unit, with a determined early to middle Tortonian age, should be correlated with the Deurne and Dessel Members of the Diest Formation. No correlative unit of the bulk of the Campine Diest Formation, late Tortonian to Messinian, could be identified in the
Maaseik core, implying that no sediments were deposited here during this time or that these sediments were later eroded prior to deposition of unit ' $\mathrm{X}$ ', supposed to be of upper Messinian age based on the biostratigraphical interpretation in Vandenberghe et al. (2005). Vandenberghe et al. (2005) have given conflicting information on the chronostratigraphic age of bed ' $\mathrm{X}$ ': on the one hand they interpreted it as dinocyst biochron DN9 being Tortonian but on the other hand, based a correlation with the Nieder Ochtendhausen research borehole in North Germany, they proposed a Syltian age, ranging from uppermost Tortonian to the end Messinian (Louwye \& Vandenberghe, 2020, this volume).

Heavy mineral contents are significantly different in the lower and upper part of the Waubach Member of the Kieseloolite Formation in the Maaseik borehole. The heavy mineral composition of the upper Waubach Member is very similar, nearly identical, to the heavy mineral composition of the Kasterlee-sensu-Gulinck unit (or lower Mol unit) and the Mol Formation, supporting a correlation between these units. The lower Waubach Member has a much larger content of zircon, contains nearly no $\mathrm{Al}_{2} \mathrm{SiO}_{5}$ polymorphs and has a larger amount of garnet and amphibole. There is no unit in the Campine Basin which has a similar composition, yet it can be best compared to the clayey Kasterlee unit. The ' $\mathrm{X}$ ' unit as well cannot be easily compared to a unit in the Campine Basin because of its lack of $\mathrm{Al}_{2} \mathrm{SiO}_{5}$ polymorphs and large amount of ultrastable minerals; yet it mostly resembles the Antwerp Campine Diest Formation and typical Kasterlee Formation based on its amount of staurolite, tourmaline, epidote and amphibole. The Breda Formation below the ' $\mathrm{X}$ ' unit mostly resembles the Dessel Member and the lower Miocene units of the Campine Basin and Hageland area, in line with the biostratigraphic data in Vandenberghe et al. (2005).

Based on the heavy mineral composition described above, a correlation between the upper Waubach Member in the RVG and the Kasterlee-sensu-Gulinck unit and Mol Formation in the Campine Basin is proposed (Fig. 16). Consequently, the lower Waubach Member can be correlated with the Diest 'member' and the clayey Kasterlee unit, as a lateral fluvial unit which was deposited in the RVG during the Tortonian and Messinian, coeval with the deposition of shallow marine glauconitic sand in the Campine Basin. Possibly, this lower Waubach Member should then in fact be redefined as the Inden Formation, which is expected to be deposited at this location coeval to the Campine Diest 'member' (Vandenberghe et al., 2014) (Fig. 1). The contrast

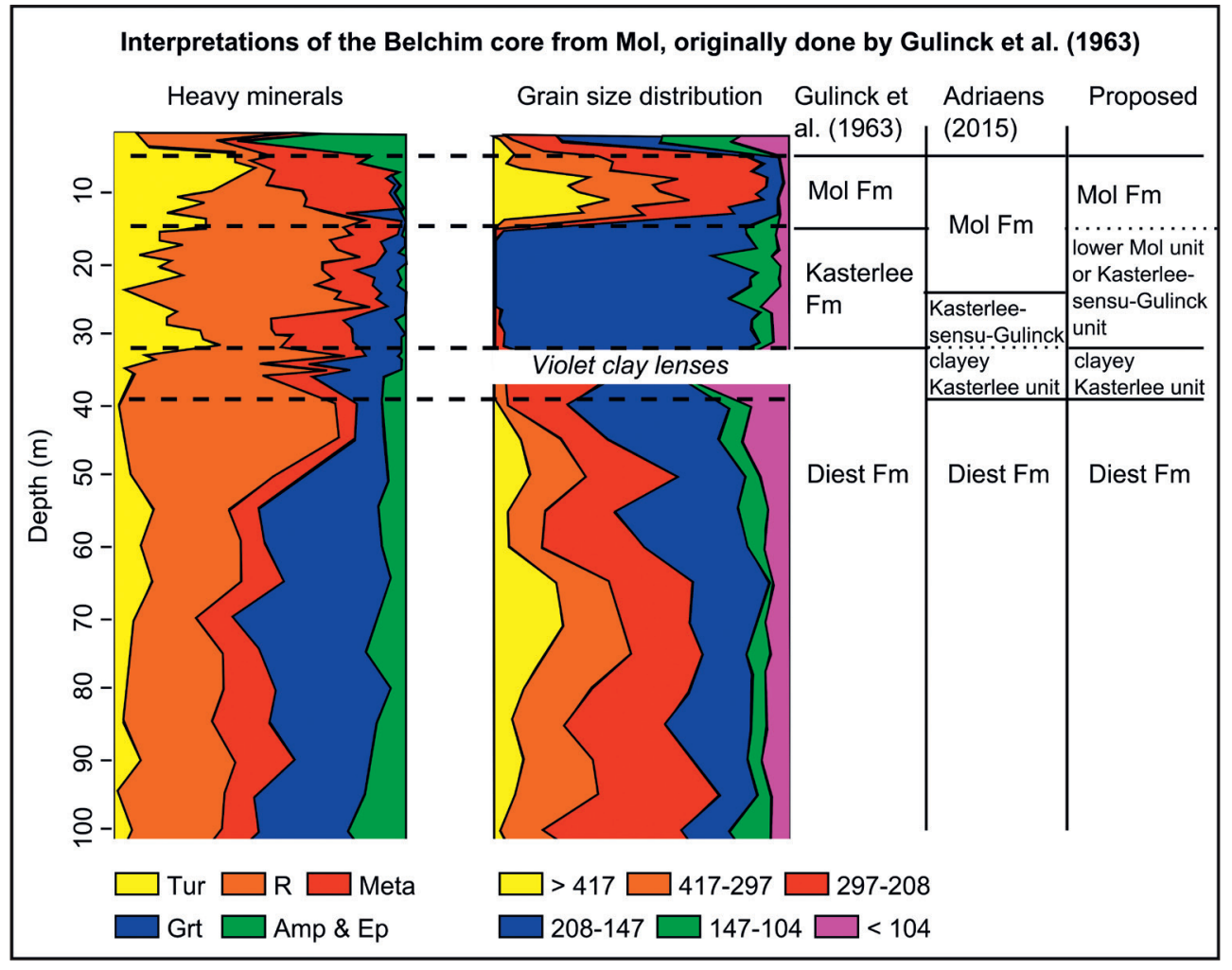

Figure 15. Heavy mineral composition and grain size distribution from the Belchim core in Mol, adapted from Gulinck et al. (1963). The stratigraphic interpretation by Gulinck et al. (1963), the current practice (see interpretations in Adriaens, 2015) and the new interpretation proposed in Vandenberghe et al. (2020, this volume). Heavy minerals: Tur $=$ tourmaline, $\mathrm{R}=$ zircon + rutile, Meta $=$ staurolite, kyanite, andalusite and sillimanite, Grt = garnet, Amp \& Ep = amphibole and epidote. Grain size fractions are given in $\mu \mathrm{m}$. 
Figure 16. Correlation between the Dessel cores of the centra Campine Basin and the Maaseik core of the RVG. Heavy mineral composition (with heavy mineral classes) and grain size distribution (with grain size intervals) are given for each core. Each knickpoint in the curves represents an analyzed sample. $\mathrm{Zrn}=$ zircon, Ti-group = titanium-group minerals (mainly rutile), Other $=$ accessory minerals, Tur $=$ tourmaline, $\mathrm{Ky}$ $=$ kyanite, And = andalusite, Sil $=$ sillimanite, $\mathrm{St}=$ staurolite, Grt $=$ garnet, Ep-group $=$ epidote-group minerals (mainly epidote and clinozoisite), $\mathrm{Hb}$ $=$ hornblende, Amp = other amphiboles.

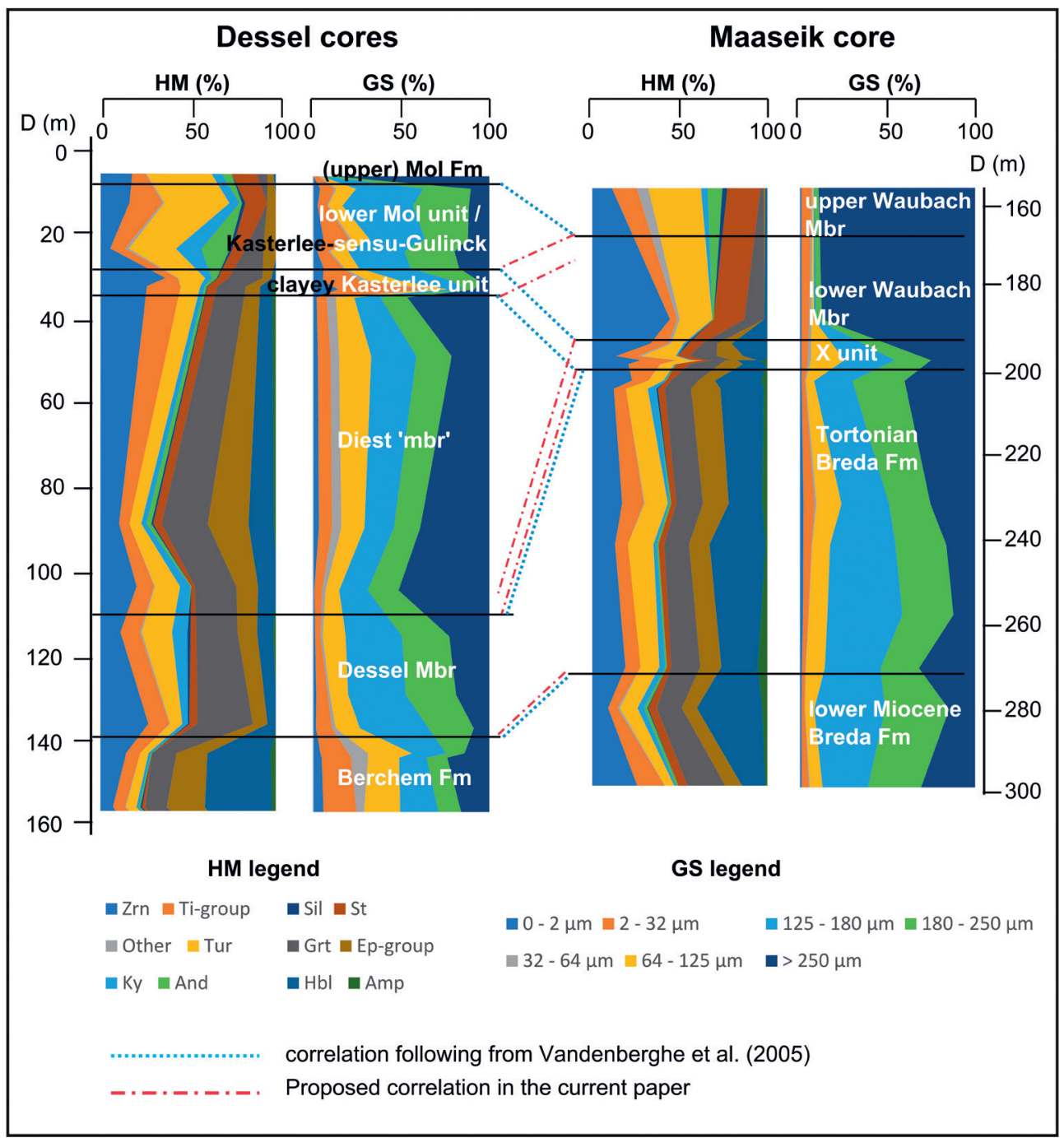

in heavy mineral composition between these units can be explained by their different nature as marine versus continental units and related differing provenance, also illustrated by the contrast in glauconite content. The ' $\mathrm{X}$ ' unit is interpreted as a semi-continental near-shore transitional unit in between the marine Breda Formation and the continental Kieseloolite/Inden Sand and should then be roughly correlated with the transition between the Dessel Member and Diest 'member' in the Campine Basin (Fig. 16). Finally, the marine glauconitic sand of the Breda Formation below the ' $X$ ' unit is correlated with the Dessel and Deurne Members of the Diest Formation, deposited during the early Tortonian, as proposed by Vandenberghe et al. (2005).

This interpretation conforms well with the conceptual model for the Diest Formation by Vandenberghe et al. (2014) which predicts the presence of fluvial Inden Sand in the RVG coeval to the Diest 'member'. Based on this interpretation, no lack of sedimentation or strong erosional event is necessary at Maaseik in between the top of the Breda Formation and the ' $\mathrm{X}$ ' unit in order to explain the lack of an upper Tortonian to Messinian correlative unit of the Diest Formation. An important contrast still exists between the correlation proposed in the current paper and the Messinian age of the ' $\mathrm{X}$ ' unit proposed in Vandenberghe et al. (2005). However, based on these new insights, the samples analyzed for heavy mineral composition in this study were also analyzed for dinoflagellate cyst biostratigraphy. The result of this analysis confirms a late Tortonian age for the ' $X$ ' unit, which fits with the interpretation proposed in the current paper (Louwye \& Vandenberghe, 2020, this volume).

\section{Concluding remarks}

A new data set of samples from boreholes and outcrops of Neogene sediments in the Campine Basin and Ruhr Valley
Graben were collected and analyzed for grain size distribution and heavy mineral composition. Statistical methods were applied to these data to circumvent the classical problems related to the interpretation of compositional data. The results were compared to an existing analysis of literature data which were analyzed in a similar manner. General conclusions reached as far back as the first half of the $20^{\text {th }}$ century broadly distinguishing a northern marine and southern continental association could be confirmed and more detailed distinctions between groups could be made, with a constant marine provenance in the western Campine area and a strongly increasing southern continental provenance throughout the Neogene in the central and eastern Campine area.

In addition, the combination of heavy mineral analysis with the more detailed modern stratigraphic subdivisions in the Neogene of Belgium allowed to refine the paleogeographic evolution of the area and to propose equivalences between units. Based on the results presented in this study, it has been demonstrated that heavy mineral composition can indeed be useful information for the distinction between different stratigraphic units, to be used in conjunction with other sediment characteristics such as grain size distribution, bulk petrography and clay mineralogy. In particular: - There is a clear distinction between the lower Miocene Berchem and Bolderberg Formations, even between the marine Berchem Formation and marine Houthalen Member. This justifies the continued separation of these formations.

- The Flemish Hills sand does not directly resemble any other Neogene unit, yet the unit most similar is the Hageland Diest sand. No strong conclusions could be drawn for the correlation of those units due to the strongly weathered state of the Flemish Hills sand. The marine character of the Flemish Hills 'formation', based on its glauconite content, and the strongly weathered state of the glauconite in this 'formation', indicate 
that the initial, likely more mixed marine, heavy mineral signature was strongly altered due to chemical weathering. There is a significant difference between the Diest Formation of the Antwerp Campine Basin and Dessel Member of the Hageland area on the one hand, and the Hageland Diest sand on the other hand. The strong difference between the Dessel Member and the Hageland Diest sand suggests that these sediments were deposited in successive sequences with a changing provenance.

- The distinction between the clayey Kasterlee unit and the Kasterlee-sensu-Gulinck unit or lower Mol unit is justified based on the heavy mineral composition. The clayey Kasterlee unit has a slightly enriched southern signature compared to the underlying Diest Formation, yet there is a very strong break with the overlying Kasterlee-sensu-Gulinck unit. The Kasterlee-sensu-Gulinck unit strongly resembles the overlying Mol Formation in which the southern provenance signature is dominant. Based on this result an integration of this Kasterlee-sensu-Gulinck or lower Mol unit into an extended Mol Formation seems logical.

- Based on the heavy mineral composition, the continental lower Waubach Member could be interpreted as a lateral equivalent to the marine upper Miocene Diest and Kasterlee Formations. If this is the case, the lower Waubach Member in the Maaseik core can be redefined as part of the Inden Formation. As a result of this correlation, the clayey Kasterlee Formation in the Campine Basin and the ' $\mathrm{X}$ ' bed at the top of the Breda Formation in the Ruhr Valley Graben are no longer correlated.

- The similarity in heavy mineral composition between middle Eocene units and upper Miocene to Pliocene units, as marked by andalusite content, points to a provenance area that continued to deliver the same association of minerals over a very long time during many changing paleogeographic conditions and/or with eventual reworking of the association in younger stratigraphic units. A similar heavy mineral association thus does not immediately warrant a stratigraphic correlation between units.

Similarly, units with different heavy mineral associations are not necessarily different chronostratigraphic units but can be lateral lithostratigraphic facies within the same time slice as is the case for the continental Mol Formation and the marine Poederlee Formation and possibly for the Kasterlee-sensuGulinck unit and typical Kasterlee Formation.

The same lithostratigraphic unit can also have different heavy mineral associations in it in case several sediment sources are contributing to the unit as is the case with the Diest Formation.

\section{Acknowledgements}

This research was funded by FWO (Flemish Research Foundation) grant 1105816 N. Many thanks to Professor Noël Vandenberghe for his detailed comments on the first drafts of this paper and to the reviewers, Professor Hilmar von Eynatten and Professor Jan Elsen for their constructive remarks.

\section{References}

Adriaens, R. 2015. Neogene and Quaternary clay minerals in the southern North Sea. Unpublished Ph.D. Thesis, KU Leuven, Leuven, 272 p.

Aitchison, J., 1986. The Statistical Analysis of Compositional Data. Chapman and Hall, London, 416 p.

De Breuck, W., 1959. Bijdrage tot de kennis van de sedimentpetrologie van het Tertiair in België. Unpublished Ph.D. Thesis, Rijksuniversiteit Gent, Faculteit der Wetenschappen, Ghent, 141 p.

Edelman, C.H. \& Doeglas, D.J., 1933. Bijdrage tot de petrologie van het Nederlandsche Tertiair. Verhandelingen van het Geologischmijnbouwkundig genootschap voor Nederland en koloniën, Geologische serie, 10, 1-38.

Geets, S. \& De Breuck, W., 1991. De zware-mineraleninhoud van Belgische Mesozoïsche en Cenozoïsche afzettingen. Neogeen. Natuurwetenschappelijk Tijdschrift, 73, 3-37.

Geets, S., De Breuck, W. \& Jacobs, P., 1985. De zware-mineraleninhoud van Belgische Mesozoïsche en Cenozoïsche afzettingen. E. Middenen Boven-Eoceen. Natuurwetenschappelijk Tijdschrift, 67, 3-25.
Gulinck, M., Geets, S. \& Van Voorthuyzen, J.H., 1963. Note sur les sondages du Centre Nucléaire à Mol. Bulletin de la Société belge de Géologie, 72, 283-394.

Gullentops, F., 1957. L'origine des collines du Hageland. Bulletin de la Société belge de Géologie, 66, 81-85.

Gullentops, F., 1963. Etude de divers facies quaternaires et tertiaires dans le Nord et 1'Est de la Belgique. Excursion O-P, 6e Congrès International de Sédimentologie 1963, Belgique et Pays-Bas.

Gullentops, F., 1973. Grainsize and mineralogy of Miocene glass-sands of Maasmechelen, Belgian Limburg. Mededelingen Rijks Geologische Dienst, Nieuwe Serie, 23, 25-34.

Gullentops, F. \& Huyghebaert, L., 1999. A profile through the Pliocene of Northern Kempen, Belgium. Aardkundige Mededelingen, 9, 191202.

Houthuys, R., 2014. A reinterpretation of the Neogene emersion of central Belgium based on the sedimentary environment of the Diest Formation and the origin of the drainage pattern. Geologica Belgica, 17, 211-235.

Houthuys, R. \& Matthijs, J., 2018. The Hageland hills, legacies of the depositional architecture of the Miocene Diest Sands. In Demoulin, A. (ed.), Landscapes and Landforms of Belgium and Luxembourg. Springer, Cham, 237-252. https://doi.org/10.1007/978-3-319-58239914

Janssens, L., 2017. Mineralogical study of the stratigraphic position of the sandy deposits of the Flemish Hills. Unpublished Master Thesis, KU Leuven, Leuven $85 \mathrm{p}$

Larue, J.-P. \& Etienne, R., 2000. Les Sables de Lozère dans le Bassin parisien: nouvelles interprétations. Géologie de la France, 2, 81-94.

Louwye, S. \& Vandenberghe, N., 2020. A reappraisal of the dinoflagellate cyst biostratigraphy of the upper Miocene in the Maaseik well 49W0220. Geologica Belgica, 23, 3-4, this volume. https://doi. org/10.20341/gb.2020.013

Louwye, S., Deckers, J., Verhaegen, J., Adriaens, R. \& Vandenberghe, N., 2020. A review of the lower and middle Miocene in northern Belgium. Geologica Belgica, 23, 3-4, this volume. https://doi. org/10.20341/gb.2020.010

Mange, M.A. \& Maurer, H.F.W., 1992. Heavy Minerals in Colour. Chapman \& Hall, London, 147 p. https://doi.org/10.1007/978-94011-2308-2

Mange, A. \& Wright, D.T. (eds), 2007. Heavy Minerals in Use. Elsevier, Amsterdam, Developments in Sedimentology, 58, 1283 p.

Morton, A.C. \& Hallsworth, C., 1994. Identifying provenance-specific features of detrital heavy mineral assemblages in sandstones. Sedimentary Geology, 90, 241-256. https://doi.org/10.1016/00370738(94)90041-8

Morton, A.C. \& Hallsworth, C.R., 1999. Processes controlling the composition of heavy mineral assemblages in sandstones. Sedimentary Geology, 124, 3-29. https://doi.org/10.1016/S00370738(98)00118-3

Schäfer, A. \& Utescher, T. 2014. Origin, sediment fill, and sequence stratigraphy of the Cenozoic Lower Rhine Basin (Germany) interpreted from well logs. German Journal of Geology (ZDGG), 165, 287-314. https://doi.org/10.1127/1860-1804/2014/0062

Schäfer, A., Utescher, T., Klett, M. \& Valdivia-Manchego, M., 2005. The Cenozoic Lower Rhine Basin - rifting, sedimentation, and cyclic stratigraphy. International Journal of Earth Sciences, 94, 621-639. https://doi.org/10.1007/s00531-005-0499-7

Tavernier, R., 1943. Le Néogène de la Belgique. Bulletin de la Société Belge de Géologie, 52, 7-34.

Vandenberghe, N., Van Simaeys, S., Steurbaut, E., Jagt, J.W.M. \& Felder, P.J., 2004. Stratigraphic architecture of the Upper Cretaceous and Cenozoic along the southern border of the North Sea Basin in Belgium. Netherlands Journal of Geosciences, 83, 155-171. https:// doi.org/10.1017/S0016774600020229

Vandenberghe, N., Laga, P., Louwye, S., Vanhoorne, R., Marquet, R., De Meuter, F., Wouters, K. \& Hagemann, H.W., 2005. Stratigraphic interpretation of the Neogene marine-continental record in the Maaseik well (49W0220) in the Roer Valley Graben, NE Belgium. Memoirs of the Geological Survey of Belgium, 52, $39 \mathrm{p}$.

Vandenberghe, N., Harris, W.B., Wampler, J.M., Houthuys, R., Louwye, S., Adriaens, R., Vos, K., Lanckacker, T., Matthijs, J., Deckers, J., Verhaegen, J., Laga, P., Westerhoff, W. \& Munsterman, D., 2014. The implications of K-Ar glauconite dating of the Diest Formation on the paleogeography of the Upper Miocene in Belgium. Geologica Belgica, 17, 161-174.

Vandenberghe, N., Wouters, L., Schiltz, M., Beerten, K., Berwouts, I., Vos, K., Houthuys, R., Deckers, J., Louwye, S., Laga, P., Verhaegen, J., Adriaens, R. \& Dusar, M., 2020. The Kasterlee Formation and its relation with the Diest and Mol Formations in the Belgian Campine. Geologica Belgica, 23, 3-4, this volume. https://doi.org/10.20341/ gb.2020.014 
Verhaegen, J., Adriaens, R., Louwye, S., Vandenberghe, N. \& Vos, K., 2014. Sediment-petrological study supporting the presence of the Kasterlee Formation in the Heist-op-den-Berg and Beerzel hills, southern Antwerp Campine, Belgium. Geologica Belgica, 17, 323 332.

Verhaegen, J., Weltje, G.J. \& Munsterman, D., 2019. Workflow for analysis of compositional data in sedimentary petrology: provenance changes in sedimentary basins from spatio-temporal variation in heavy-mineral assemblages. Geological Magazine, 156/7, 11111130. https://doi.org/10.1017/S0016756818000584

Verhaegen, J., Frederickx, L. \& Schiltz, M., 2020. New insights into the stratigraphy and paleogeography of the Messinian Kasterlee Formation from the analysis of a temporary outcrop. Geologica Belgica, 23, 3-4, this volume. https://doi.org/10.20341/gb.2020.015

Wentworth, K., 1922. A scale of grade and class terms for clastic sediments. Journal of Geology, 30, 377-392. https://doi.org/10.1086/622910

Westerhoff, W.E., 2009. Stratigraphy and sedimentary evolution: The lower Rhine-Meuse system during the Late Pliocene and Early Pleistocene (southern North Sea Basin). Ph.D. Thesis, Vrije Universiteit Amsterdam, Amsterdam, 168 p. 